Susana Elaine Alves da Rosa

\title{
Regulação da homeostasia do retículo endoplasmático em linfócitos B na imunodeficiência comum variável
}

Dissertação apresentada ao Programa de Pós-Graduação em Imunologia do Instituto de Ciências Biomédicas da Universidade de São Paulo, para obtenção do Titulo de Mestre em Ciências. 
Susana Elaine Alves da Rosa

\section{Regulação da homeostasia do retículo endoplasmático em linfócitos B na imunodeficiência comum variável}

Dissertação apresentada ao Programa de

Pós-Graduação em Imunologia do Instituto de Ciências Biomédicas da Universidade de São Paulo, para obtenção do Titulo de Mestre em Ciências.

Área de concentração: Imunologia

Orientadora: Prof. Dra. Maristela Martins de Camargo

Versão Original

São Paulo

2011 
DADOS DE CATALOGAÇÃO NA PUBLICAÇÃO (CIP)

Serviço de Biblioteca e Informação Biomédica do

Instituto de Ciências Biomédicas da Universidade de São Paulo

reprodução não autorizada pelo autor

Rosa, Susana Elaine Alves da.

Regulacão da homeostasia do retículo endoplasmático em linfócitos B na imunodeficiência comum variável / Susana Elaine Alves da Rosa. -- São Paulo, 2011.

Orientador: Maristela Martins de Camargo.

Dissertação (Mestrado) - Universidade de São Paulo. Instituto de Ciências Biomédicas. Departamento de Imunologia. Área de concentração: Imunologia. Linha de pesquisa: Imunorregulação molecular.

Versão do título para o inglês: Regulation of homeostasis of endoplasmic reticulum in $\mathrm{B}$ lymphocytes in common variable immunodeficiency.

Descritores: 1. Linfócitos B 2. Anticorpos 3. CVID 4. LPS 5. Via UPR I. Camargo, Maristela Martins de II. Universidade de São Paulo. Instituto de Ciências Biomédicas. Programa de Pós-Graduação em Imunologia III. Título. 
Título da Dissertação: $\quad$ Regulacão da homeostasia do retículo endoplasmático em linfócitos B na imunodeficiência comum variável.

Orientador(a): $\quad$ Maristela Martins de Camargo.

A Comissão Julgadora dos trabalhos de Defesa da Dissertação de Mestrado, em sessão pública realizada a /...............................,
( ) Aprovado(a)
( ) Reprovado(a)

Examinador(a): Assinatura:

Nome:

Instituição:

Examinador(a): Assinatura:

Nome:

Instituição:

Presidente: Assinatura:

Nome:

Instituição: 


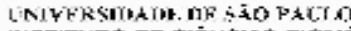

INSTITUTO DE CIËNCIAS BIONĖDICAS

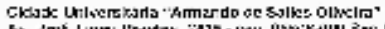

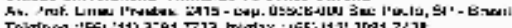

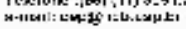

Söo Pauk. 25 ṫ : :

\section{P.ARFC.FR R92:CEP}

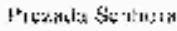

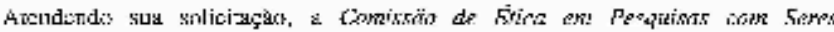

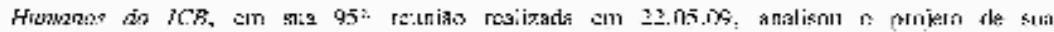

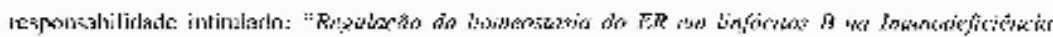

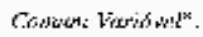

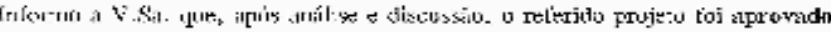
per e'sta Comissūo.

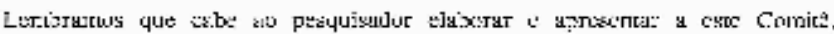

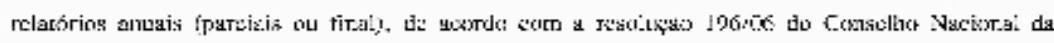
Saide, imem TX.2 letru c.

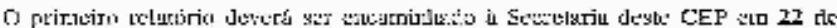
main de 2010

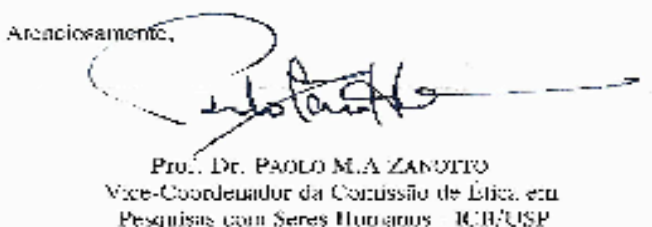

Den Sirk.

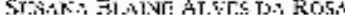

Dheparrankiors is Thun ining

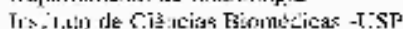

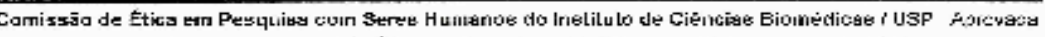

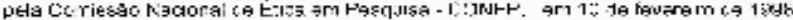


À Deus, que me acompanha em todos os momentos, me ama e fortalece e me torna capaz de superar os obstáculos mais difíceis.

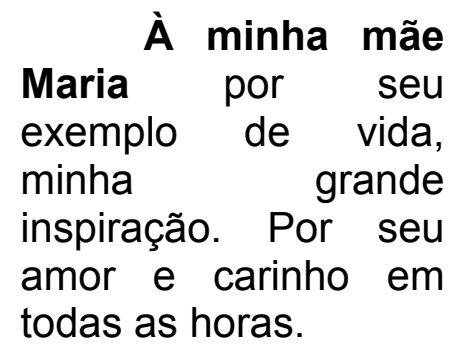

Às minhas irmãs Patrícia e Maria Fernanda por serem mais do que irmãs. Pelo carinho e apoio. Aos meus amados sobrinhos Luis Felipe e Letícia, por alegrarem a minha vida.

À minha tia Sueli, por todas as oportunidades de crescer profissionalmente e pessoalmente. Pelo carinho e incentivo. 


\section{AGRADECIMENTOS}

À Prof. Maristela Martins de Camargo pelos ensinamentos e pela confiança no meu trabalho.

À Dra. Cristina Kokron do Serviço de Imunologia e Alergia do Hospital de Clínicas da Universidade de São Paulo que viabilizou a coleta das amostras dos pacientes.

À técnica de enfermagem Rosana pela coleta das amostras dos pacientes.

À Dra. Luiza Guilherme Guglielmi pela imortalização dos linfócitos B.

Aos professores José Alexandre Marzagão Barbuto, João Gustavo Pessini Amarante Mendes e Eliana Faquim de Lima Mauro pela grande contribuição no exame de qualificação.

Aos amigos Thiago Clemente e Tarcio Braga pela disponibilidade e a gentileza em colher as amostras de sangue dos indivíduos saudáveis.

Aos alunos e funcionários que doaram amostras de sangue para realização deste projeto.

Aos colegas de laboratório que estiveram presentes ao longo deste projeto:

Bruno Miotto, Camila Doll, Camila Bonin Pinto, Caue Zortea e Fernanda Sodré pela amizade e companherismo.

À Camila Bonin Pinto e Tatiana Fraga por me ensinarem o valor de uma verdadeira amizade. Pelo carinho e apoio em todas horas e por terem sido fundamentais para a realização deste projeto.

Aos amigos do Departamento de Imunologia do ICB - USP pela amizade e pelas experiências compartilhadas.

Aos docentes do Departamento de Imunologia do ICB - USP por todos os ensinamentos e pela disponibilidade em compartilhar reagentes e equipamentos.

A todos os funcionários do Departamento de Imunologia do ICB - USP por contribuírem de uma forma ou de outra para a realização deste projeto. 


\section{RESUMO}

Rosa SEA. Regulação da via UPR no retículo endoplasmático em linfócitos $B$ na imunodeficiência comum variável. [dissertação (Mestrado em Imunologia)]. São Paulo: Instituto de Ciências Biomédicas da Universidade de São Paulo; 2011.

A imunodeficiência comum variável (CVID) é caracterizada por hipogamaglobulinemia. Anteriormente identificou-se uma paciente com CVID que apresenta nível aumentado de estresse de retículo endoplasmático (ER), secundário a desregulação da via UPR. No presente trabalho, estendemos esta análise para outros pacientes e avaliamos o perfil de maturação de seus linfócitos B. Métodos: Western-blot, RT-PCR, Q-PCR, Citometria de Fluxo e cultura de células B ex vivo e imortalizadas. Resultados: A análise de 16 pacientes com CVID e 9 indivíduos saudáveis revelou três pacientes com porcentagens aumentadas de linfócitos $B$ imaturos no sangue periférico. A análise da expressão de RNAm para BiP e XBP-1 em linfócitos B destes pacientes, após estímulo com LPS in vitro, identificou que os linfócitos B de um deles apresenta estresse de RE. Conclusão: Identificamos um subgrupo de pacientes com CVID que apresentam linfócitos $B$ imaturos no sangue periférico. Um membro deste subgrupo apresenta estresse aumentado de ER.

Palavras-chave: CVID. Unfolded Protein Response. Anticorpos. Linfócitos B. LPS. 


\begin{abstract}
Rosa SEA. Regulation of the UPR pathway in B lymphocytes during Common Variable Immunodeficiency. [Masters thesis (Immunology)]. São Paulo: Instituto de Ciências Biomédicas da Universidade de São Paulo; 2011.

Common Variable Immunodeficiency (CVID) is characterized by hypogammaglobulinemia. Previously a CVID patient was identified with increased levels of Endoplasmic Reticulum (ER) stress due to dysregulation of the UPR. In the present study these analyses were performed in other patients and healthy donors. Maturation markers of $B$ lymphocytes were also characterized in these individuals. Methods: Western-blot, RT-PCR, Q-PCR, Flow cytometry and culturing of ex vivo and immortalized B cells. Results: The analysis of 16 CVID patients and 9 healthy donors revealed three patients that present higher percentage of immature $B$ cells in peripheral blood. Analysis of expression of BiP and XBP1 induced by LPS treatment of $B$ lymphocytes from these patients revealed that one patient present increased levels of ER stress. Conclusion: We identified a sub-group of CVID patients that present immature B lymphocytes in periphery. One member of this subgroup shows increased ER stress.
\end{abstract}

Keywords: CVID. Unfolded Protein Response. Antibodies. B lymphocytes. LPS. 


\section{SUMÁRIO}

1 INTRODUCÃO

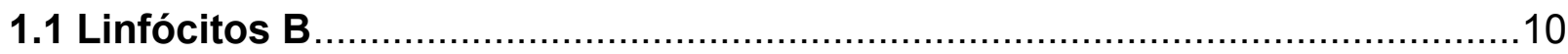

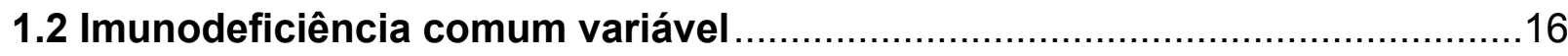

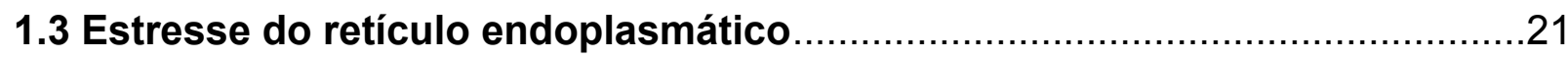

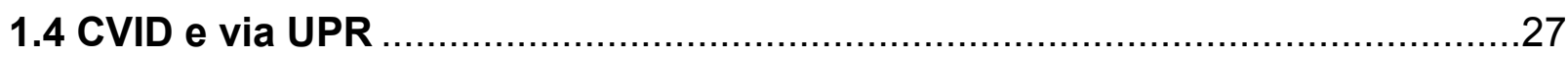

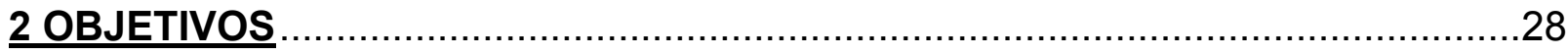

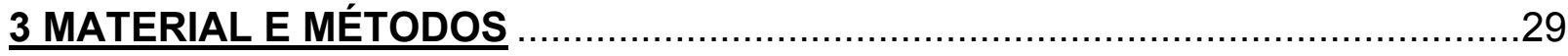

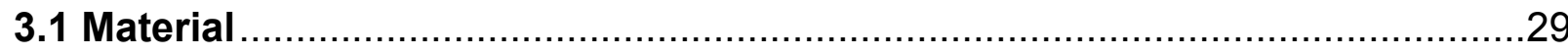

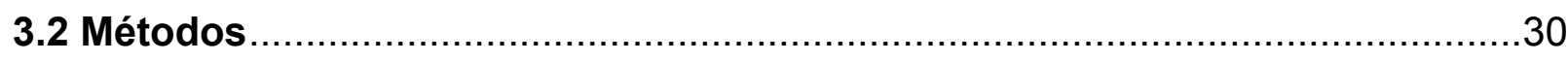

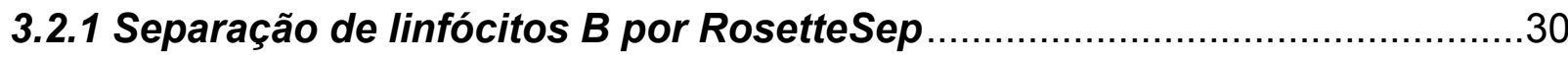

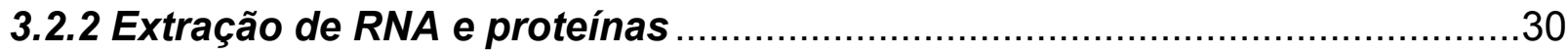

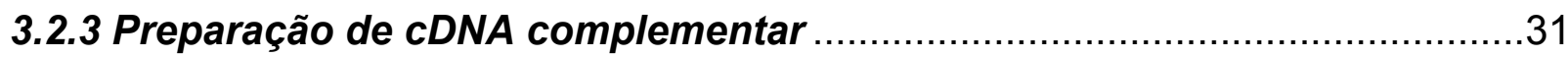

3.2.4 Reação em cadeia da polimerase (PCR) em tempo real (qPCR) ..................31

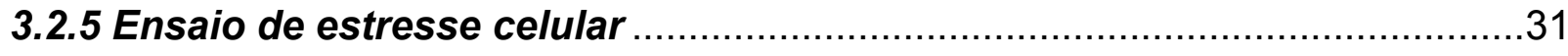

3.2.6 Caracterização dos linfócitos de sangue periférico ……............................32

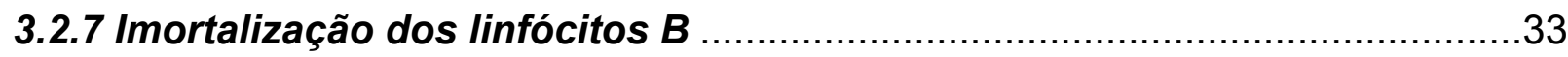

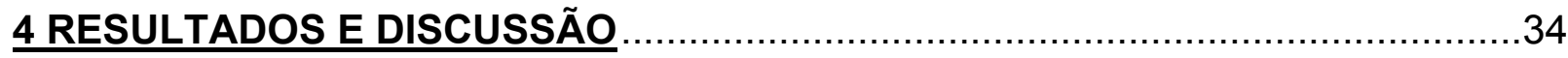

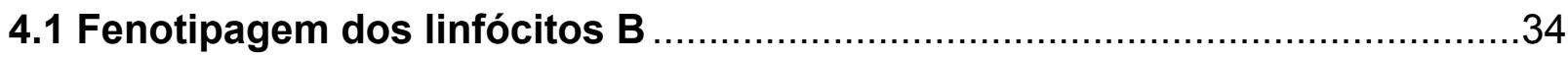

4.2 Avaliação da via UPR em linfócitos B de pacientes com CVID ………...........48

4.3 Cinética de ação do LPS em células B imortalizadas com vírus Epstein

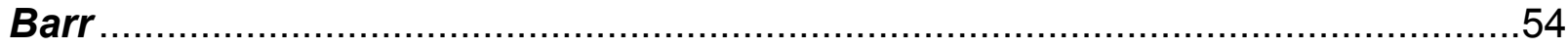

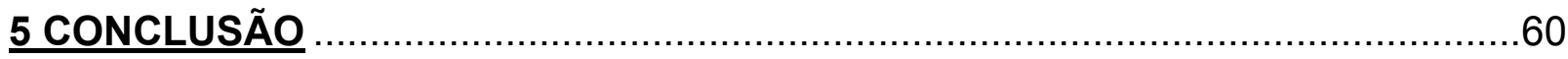

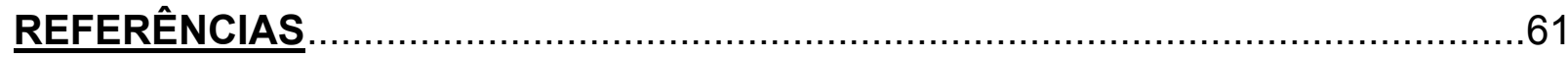




\section{INTRODUÇÃO}

\subsection{Linfócitos B}

São células do sistema imune que possuem em sua superfície imunoglobulinas capazes de reconhecer epítopos antigênicos específicos. A descoberta e a caracterização dessas células ocorreu em meados de 1960 através de experimentos com modelos animais, avaliação clínica de pacientes com imunodeficiências e pela caracterização de moléculas de superfície celular (Good e Zak, 1956). A identificação da imunoglobulina ou anticorpo aconteceu previamente (Tisilius e Kabat, 1938), sendo importante para a caracterização de plasmócitos como células produtoras de anticorpos (Fagraeus, 1948).

O desenvolvimento dos linfócitos $\mathrm{B}$ em humanos ocorre inicialmente no fígado fetal e posteriormente na medula óssea e envolve um processo de rearranjos dos segmentos gênicos dos loci das cadeias leves e pesadas da imunoglobulina. Isso leva a geração de um repertório diversificado e funcional do receptor de células $B$ (BCR) (Brack et al, 1978).

Esse processo requer um controle preciso feito pela combinação de citocinas e fatores de transcrição que regulam a expressão de genes em diferentes estágios para promover a diferenciação de células, sobrevida e proliferação (Schesbesta, 2002; Bartholdy e Matthias, 2004).

Fatores de transcrição críticos no comprometimento com a linhagem B incluem o E2A, EBF1 (early B-cell factor 1) e Pax5 (paired Box protein 5). Outros, tais como OCT (octamer-binding transcription), OBF1 (oct binding factor 1), NFkB (nuclear factor kappa-light chain enhancer of activated B cell) são importantes nos estágios finais. Enquanto que XBP-1 (X-box binding protein 1) e BLIMP1 ( $B$ lymphocyte inducer of maturation program 1) são importantes no processo de diferenciação de linfócitos B em plasmócitos (Bartholdy e Matthias, 2004).

Os fatores de transcrição E2A e EBF1 agem de modo similar nos estágios iniciais de desenvolvimento dos linfócitos $B$ e podem juntos aumentar a regulação da expressão de genes específicos de células B tais como: cadeia substituta $\lambda 5 \mathrm{e}$ VpreB, as moléculas de sinalização $\lg \alpha$ e $\lg \beta$ e as proteínas RAG1 e RAG2 (Sigvardisson et al, 1997; O'Riordan e Grosschedl, 1999).

O Pax5 é um fator de transcrição multifuncional expresso ao longo de todo o 
desenvolvimento dos linfócitos $B$ desde o estágio pró-B até o estágio de célula $B$ madura (Busslinger, 2004; Sing et al, 2005). Além do comprometimento com a linhagem B, o Pax5 está envolvido no rearranjo dos genes da imunoglobulina (Nut et al, 1997). Genes alvos do Pax5 incluem os genes que codificam a molécula de superfície CD19, a molécula de sinalização CD79a $(\lg \alpha)$ e as cadeias substitutas $\lambda 5$ e VpreB (Kozmik et al, 1992; Okabe et al, 1992; Fitzsimmons et al, 1996).

O fator de transcrição OBF1 é expresso predominantemente em células B e forma um complexo ternário com os fatores de transcrição Oct1 e Oct2 em regiões conservadas de imunoglobulinas e outros genes (Bordon et al, 2008). Camundongos deficientes em OBF1 apresentam desenvolvimento inicial de células B normal na medula, mas número reduzido de linfócitos $B$ periféricos, uma resposta imune humoral dependente de linfócitos $T$ prejudicada e baixos níveis de imunoglobulina lgG (Kim et al, 1996).

Diversas formas de subunidades de NF-kB são expressos ao longo de todo o processo de desenvolvimento de linfócitos $B$ e estudos com camundongos mutantes para as subunidades p50 e p52 mostraram um defeito no desenvolvimento final dos linfócitos $B$ com diminuição no número de células $B$ maduras e aumento de células imaturas (Franzoso et al, 1997).

O número de linfócitos $B$ permanece constante em indivíduos adultos. Esta homeostasia é resultado da natureza complexa do seu desenvolvimento e maturação que permite a sobrevivência e produção constante de células $B$ protetoras, mas também assegura a eliminação de células B auto-reativas. A manutenção dessa homeostasia é dependente de dois fatores importantes: um BCR funcional e da molécula BAFF ( $B$ cell-activating factor of the TNF family) (Mackay et al, 2010).

BAFF existe na forma trimérica ligada a membrana e pode permanecer assim ou ser liberada como um trímero solúvel depois da clivagem da superfície celular. É produzido principalmente por neutrófilos, monócitos e macrófagos e tem como ligantes O TACl (transmembrane activator and calcium-modulator and cyclophilin ligand interactor), o BCMA ( $B$ cell maturation protein $A$ ) e o BAFFR ( $B$ cell-activating factor receptor) (Schneider et al, 1999).

A maturação dos linfócitos B pode ser dividida em diferentes estágios de acordo com o rearranjo das cadeias leves e pesadas da imunoglobulina que irão formar um BCR funcional. Uma vez comprometida com a linhagem B, as células B 
entram no estágio de célula pró-B no qual há um rearranjo parcial da cadeia pesada da imunoglobulina. No estágio pré-B, a recombinação da cadeia pesada está completa e a célula expressa um pré-BCR que é composto das cadeias leves substitutas ( $\lambda 5$ e vpreB) e as moléculas $\lg \alpha$ e $\lg \beta$. Além disso, há neste estágio o início do rearranjo da cadeia leve. Na etapa seguinte, com os rearranjos das cadeias leve e pesada completos, a célula B apresenta um BCR funcional sendo considerada imatura e continuar o processo de maturação nos órgãos linfóides secundários (Hardy e Hayakawa, 2001).

As células B imaturas são exportadas da medula óssea a medida que tornamse independentes dos fatores estromais. Vão para os órgãos linfóides secundários onde ocorrem eventos de maturação para produção de células B maduras. Estas células são chamadas de células $B$ transicionais pois representam um estágio intermediário de desenvolvimento (Rolink e Melcher, 1993; Banchereau e Rousset, 1992; Allman et al, 2001).

As células maduras por sua vez, são agrupadas em três grandes populações de acordo com sua localização anatômica, suas características fenotípicas e sua função: (1) células B foliculares (FO) que também são denominadas de células $B$ convencionais B2 e constituem a maioria das células B do baço, (2) células B de zona marginal (MZ) e (3) células B1 (Samitas et al, 2010).

Até aproximadamente 1980, o que se conhecia a respeito da superfície celular dos linfócitos B consistia na imunoglobulina de membrana, nos receptores de complemento e receptores Fc. Isso começou a mudar com o aparecimento do anticorpo monoclonal que levou a identificação de moléculas expressas nas superfícies de várias células, inclusive dos linfócitos $B$, denominadas de CD (cluster of differentiation). Dessa forma, foi possível obter maiores informações sobre a expressão e função dessas moléculas e a sua contribuição no desenvolvimento dos linfócitos B.

Ao longo de todo o processo de maturação dos linfócitos B desde a medula óssea até a periferia, essas moléculas sofrem variações na intensidade de sua expressão na superfície celular auxiliando na classificação dos estágios de maturação dos linfócitos $B$.

As células imaturas são bem definidas em camundongos sendo classificadas em T1, T2 e T3. As células B T1 são caracterizadas fenotipicamente como $\mathrm{CD}_{24}{ }^{\text {high }} \operatorname{lgM} \mathrm{M}^{\text {high }} \operatorname{lgD}^{+} \mathrm{CD} 21^{+} \mathrm{CD} 23^{+} \mathrm{CD} 93^{+}, \quad$ as células T2 são 
$\mathrm{CD} 24^{\text {high }} \operatorname{IgM}^{\text {high }} \lg { }^{\text {high }} \mathrm{CD} 21^{+} \mathrm{CD} 23^{+} \mathrm{CD} 3^{+}$e as células T3 apresentam o fenótipo CD24 ${ }^{\text {high }} \operatorname{lgM}^{\text {low }} \operatorname{lgD}^{\text {high }} \mathrm{CD} 21^{+} \mathrm{CD}_{23}{ }^{+} \mathrm{CD} 3^{+}$(Allman et al, 2001; 2004).

Em nosso trabalho as células $B$ dos indivíduos analisados foram classificadas de acordo com a expressão dos marcadores CD45, CD19, CD38, FMC7, CD5 e CD23 o que permitiu a separação destas células em quatro estágios de diferenciação: I, II, III e IV. Sendo que, as células pertencentes aos estágios I, II e III representaram as mais imaturas, enquanto que as pertencentes ao estágio IV consistiam em células maduras (Loken et al, 1987).

O CD19 é uma glicoproteína transmembrana expressa nas células B desde o estágio de célula pré-B e que permanece ao longo de processo de maturação da célula. O CD19 em associação com CD21 conectam a imunidade inata com a adaptativa facilitando o reconhecimento do complexo antígeno-anticorpo via BCR (Tedder et al,1997).

$A$ expressão de CD5 em linfócitos $B$ está restrita a subpopulação $B 1$, um tipo celular diferente dos linfócitos B convencionais (B2) no seu fenótipo, na localização anatômica, e na capacidade de auto-renovação e produção de anticorpos naturais. Os linfócitos B1 expressam baixos níveis de slgD, CD21, CD23 e expressam altos níveis de slgM. Secretam anticorpos da classe IgM, chamados de anticorpos naturais, que se ligam a antígenos comuns associados a patógenos (Hardy e Hayakawa 2001, Berland e Wortis, 2002).

No baço os linfócitos B1 representam de 1 a 5\% das células B. No linfonodo constituem menos de $1 \%$ das células, mas compreendem uma fração substancial de células B nas cavidades peritoneais e pleurais (Ansel et al, 2002).

A molécula CD45 é uma tirosina fosfatase que está presente em todas as células hematopoiéticas exceto nas plaquetas e nas hemácias. Tem a função de regular as Scr quinases que são responsáveis pela transdução do sinal dos receptores de células $T$ e $B$. A expressão desta molécula varia durante a ontogenia das células $B$, de modo que as células precursoras dos linfócitos $B$ apresentam baixos níveis de expressão de CD45 (McKenna et al, 2001) enquanto que os linfócitos B maduros expressam CD45 em alta densidade na sua superfície celular (Caldwell e Patterson, 1991).

Existem diversas isoformas do CD45, (CD45RA, CD45RB, CD45RC, CD45R0) as quais são geradas pelo splicing dos exons $4(A), 5(B)$ e $6(C)$ do domínio extracelular dessa molécula (Dawes et al, 2006). A maioria dos anticorpos 
monoclonais usados de rotina na citometria de fluxo reconhece a parte comum da molécula de CD45 (Carulli et al, 2008).

O CD23 é uma glicoproteína de membrana que tem homologia com as lectinas dependentes de cálcio. Em humanos possui duas isoformas CD23a e CD23b. A isoforma CD23a é restrita à células $B$ e a CD23b é induzida por IL-4 nas células B e em uma variedade de células hematopoiéticas (monócitos, macrófagos, linfócitos T, eosinófilos e plaquetas) (Delespesse et al, 1991).

A molécula CD23 foi inicialmente caracterizada como um receptor de baixa afinidade para IgE e está envolvida em uma grande variedade de processos biológicos tais como processos inflamatórios dependentes de $\operatorname{lgE}$, apresentação de antígenos nas células B e interações entre células $T$ e B. Está presente em baixa densidade na maioria dos linfócitos $B$ maduros e em altos níveis nos linfócitos $B$ ativados (Kikutani, 1986).

A expressão da molécula CD38 ocorre essencialmente em todos os linfócitos pré-B, plasmócitos e timócitos. Esse antígeno é expresso durante os estágios iniciais de maturação de linfócitos $T$ e $B$, há uma perda durante os estágios intermediários e ele reaparece em altos níveis em plasmócitos (Tedder et al, 1985). É uma enzima multifuncional que catalisa a síntese e hidrólise do ADP-ribose cíclico (cADPR) e o produto dessa reação é essencial para regulação intracelular de cálcio (Malavani et al, 2008).

O CD38 tem sido muito usado também como um marcador prognóstico de leucemias, especialmente na leucemia linfocítica crônica de células B (B-CLL). Foi verificado que pacientes portadores de B-CLL que apresentavam mutações nos genes da região variável da imunoglobulina e baixos números de células $\mathrm{B}$ CD38 ${ }^{+}$ apresentavam um melhor prognóstico quando comparado com pacientes que apresentavam linfócitos B com alta expressão de CD38 (Deaglio et al, 2001).

FMC7 é uma glicoproteína expressa na maioria dos linfócitos B maduros normais (Zola et al, 1987) em densidade muito variável e parece estar associada a molécula CD20 (Serke et al, 2001). Essa molécula é encontrada na maioria dos estágios das células $B$ malignas, exceto nas células $B$ de leucemias linfocíticas crônicas (LLC), sendo portanto um marcador muito utilizado para se diferenciar LLC de outras desordens malignas dos linfócitos B (Zola et al,1987; Huh e Anreeff,1994).

Muito do que se sabe sobre o desenvolvimento primário e periférico dos linfócitos $B$ vêm de estudos com camundongos. Muitos aspectos parecem similares 
em humanos, mas a compreensão do desenvolvimento periférico ainda é limitado. Não há informações a respeito do fenótipo e da frequência das células $B$ que migram da medula óssea para a periferia em humanos (Carsetti et al, 2004).

Em 2004 um estudo identificou células B transicionais humanas que expressavam altos níveis de CD24 e CD38. Essas células foram distinguidas de células B de memória pela utilização do marcador CD27 e foi observado que o fenótipo e a distribuição tecidual dessas células assemelhavam-se às células B T1 e T2 de camundongos (Carsetti et al, 2004).

Um estudo mais recente procurou definir o papel das células $B$ transicionais no desenvolvimento das células $B$ humanas avaliando o sangue periférico de indivíduos saudáveis e de pacientes pós transplante de célula tronco hematopoiéticas. Os dados obtidos revelam que células $B$ transicionais CD24 ${ }^{\text {high }} C D 38^{\text {high }}$ são predominantes no sangue de cordão umbilical (56 $\pm 4 \%$ ) e que essa proporção diminui entre a infância e a adolescência atingindo níveis equivalentes aos encontrados em adultos (4,5 $\pm 2,4 \%$ ) (Marie-Cardine et al, 2008).

Em um outro estudo foram avaliadas amostras de sangue periférico de indivíduos saudáveis por citometria de fluxo e as células $B$ circulantes foram separadas da seguinte maneira: $\mathrm{CD} 10^{+} \mathrm{CD} 19^{+} \mathrm{CD} 20^{+} \mathrm{CD} 27^{-} \mathrm{CD} 38^{+}$imaturas, $\mathrm{CD} 10^{-}$ $\mathrm{CD} 19^{+} \mathrm{CD} 20^{+} \mathrm{CD} 27^{-} \mathrm{CD} 38^{-}$naïve, $\mathrm{CD} 10^{-} \mathrm{CD} 19^{+} \mathrm{CD} 20^{+} \mathrm{CD} 27^{+} \mathrm{CD} 38^{-}$memória, $\mathrm{CD}^{-}$ $\mathrm{CD}_{19} \mathrm{CD}^{+} \mathrm{C}^{-} \mathrm{CD} 27^{++} \mathrm{CD} 38^{++}$plasmócitos e observaram que os linfócitos $\mathrm{B}$ naive e os de memória foram os mais representados enquanto que os linfócitos $B$ imaturos $e$ plasmócitos constituíram uma população menor (Caraux et al, 2010).

Foi verificado também neste trabalho uma correlação inversa estatisticamente significante tanto na porcentagem quanto em números absolutos de linfócitos $B$ de memória e plasmócitos em relação a idade dos indivíduos analisados. Isso poderia ser resultado de uma menor exposição a novos antígenos que ocorre na velhice (Caraux et al, 2010).

Um aumento de células B imaturas tem sido descritas em diversas situações clínicas. Num estudo com amostras de pacientes portadores de lúpus eritematoso sistêmico (LES) foi observado um aumento de células $B$ imaturas no sangue periférico definidas como CD2 $1^{\mathrm{lo}}, \mathrm{CD} 24^{\mathrm{hi}}$ e CD $38^{\text {hi }}$ quando comparado com amostras de indivíduos saudáveis $(6,7 \pm 1,8 \% ; 2,2 \pm 0,4 \%)$ respectivamente (Sims et al, 2005).

Um aumento de células B imaturas também tem sido observado no sangue 
periférico de pacientes portadores de HIV com doença avançada. Estas células foram identificadas como $\mathrm{CD}^{+} 0^{+}$um marcador presente nos estágios iniciais de maturação de células B. Isso poderia ser resultado de uma ativação policlonal de células com uma consequente depleção de células $B$ maduras resultando num aumento compensatório de células B imaturas na circulação periférica (Maza et al, 1987; Malaspina et al, 2006).

Em alguns pacientes com imunodeficiência (agamaglobulinemia ligada ao sexo e imunodeficência comum variável) tem sido observado a presença de maiores quantidades de células $B$ imaturas no sangue periférico caracterizadas como $\mathrm{CD} 10^{+} \mathrm{CD} 24^{\mathrm{hi}} \mathrm{CD} 38^{\mathrm{hi}}$. Sugere-se que a presença destas células possa contribuir para o quadro de hipogamaglobulinemia característico desta doença (Cuss et al, 2006).

\subsection{Imunodeficiência comum variável}

A Imunodeficiência Comum Variável (CVID - Common Variable Immunodeficiency) é a imunodeficiência primária mais comum. A doença é caracterizada por uma baixa produção de imunoglobulinas (Schwartz, 1999) e foi descrita pela primeira vez em 1953 (Janeway et al, 1953).

É definida clinicamente pela presença de três características principais: hipogamaglobulinemia envolvendo um ou mais isotipos de anticorpos ( $\lg$, $\lg A$ ou $\operatorname{lgM})$, infecções recidivantes principalmente do trato respiratório e gastrointestinal e deficiência na resposta humoral tanto relacionada à infecção natural quanto à vacinação (Patrick, 2008).

Entre os aspectos clínicos da doença, a presença de infecções sinopulmonares de repetição é um dos sinais mais comuns nos pacientes com CVID. A maioria deles (75 a 90\%) apresenta sinusites, otites, bronquites e pneumonias causados especialmente por bactérias encapsuladas (Hermaszewski e Webster, 1993). Além disso, pacientes com CVID podem apresentar com freqüência infecções gastrointestinais ocasionadas especialmente por Giardia lamblia, Campilobacter jejuni e Salmonella sp. (Daniels et al, 2007).

Alguns pacientes (5 a $8 \%$ ) podem ter doenças autoimunes, tais como púrpura trombocitopênica autoimune e a anemia hemolítica autoimune (Cunningham- 
Rundles, 2002). Há relatos de doença granulomatosa em 10 a $22 \%$ dos pacientes (Bates et al, 2004) e além disso, pacientes com CVID apresentam maiores riscos de desenvolver doenças neoplásicas tanto hematológicas quanto de tumores sólidos, especialmente linfomas (Mellemkjaer et al, 2002).

Essa doença atinge igualmente ambos os sexos com uma prevalência que vai de 1:10000 a 1:50000 podendo aparecer em qualquer fase da vida mas prevalecendo na fase adulta (Patrick et al, 2008). A maioria dos pacientes tem doença esporádica, mas 10 a $25 \%$ tem herança familiar com um padrão autossômico dominante (Schroeder et al, 2004).

O diagnóstico muitas vezes é demorado, ocorrendo num intervalo de 4 a 9 anos do início dos sintomas (Cunningham-Rundles, 1999), sendo feito após histórico de infecções recidivantes do trato respiratório, pela presença de deficiência na produção de anticorpos e exclusão de outras imunodeficiências (CunninghamRundles, 1989).

A CVID é uma doença complexa e heterogênea que pode apresentar diferentes defeitos imunológicos tanto na imunidade inata quanto na adaptativa que resultam no fenótipo comum de hipogamaglobulinemia (Figura 1). 


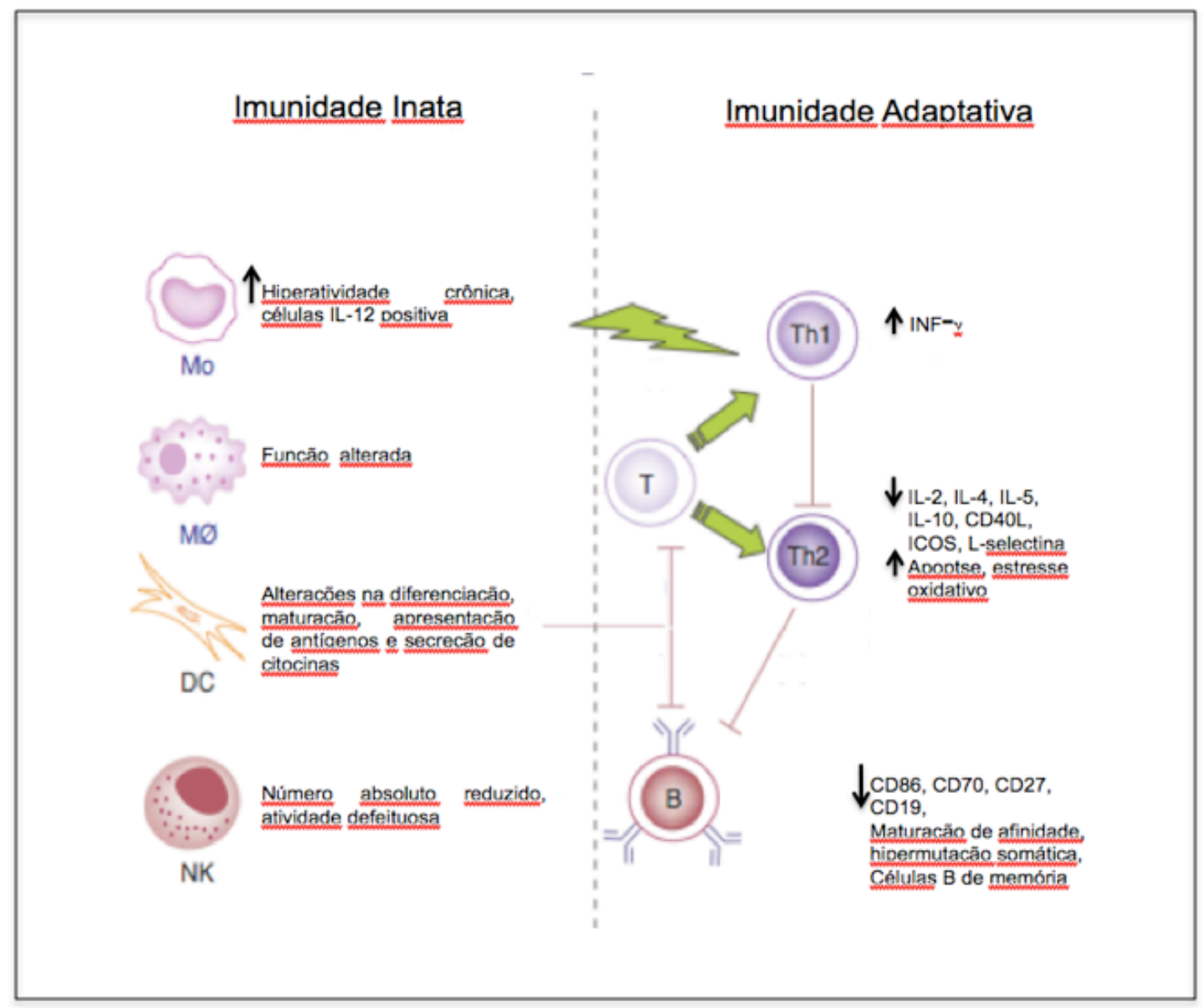

Figura 1: Representação esquemática dos defeitos em vários compartimentos do sistema imune em pacientes com CVID. Adaptado de Bayry 2005.

Em mais de $90 \%$ dos pacientes estudados nenhum defeito genético foi encontrado (Patrick et al, 2008). No entanto, em alguns pacientes foram descritos defeitos nos genes ICOS (inducible T-cell costimulator) (Grimbacher, 2003), TACI (transmembrane activator and calcium-modulator and cyclophilin ligand interactor) (Salzer et al, 2005) e CD19 (Van Zelm et al, 2006).

O primeiro registro de defeito genético associado a CVID foi o gene ICOS. Os pacientes com esta anormalidade apresentavam poucos linfócitos B no sangue periférico, hipogamaglobulinemia e número reduzido ou ausência de célula $B$ de memória (Grimbacher, 2003).

A proteína ICOS é expressa principalmente em células $\mathrm{T}$ ativadas e um dos seus papéis é a indução de IL-10, necessária para diferenciação terminal de linfócitos B em plasmócitos e células de memória. Ela se liga ao ICOS ligante (ICOSL) expresso constitutivamente em células apresentadoras de antígenos. A via de 
sinalização ativada por ICOS e seu ligante é importante para a ativação de células T auxiliares e para o estabelecimento de uma resposta anticorpo-dependente (Hutloff et al, 1999).

A proteína TACI pertence a superfamília de receptores do fator de necrose tumoral (TNFRSF) e tem como ligantes o BAFF ( $B$ cell activating factor) e APRIL ( $A$ proliferation-inducing ligand) cuja expressão ocorre principalmente em monócitos e células dendríticas (Schneider, 2005).

Mutações no gene TACI tem sido observadas em 8 a 10\% dos pacientes com CVID. Pacientes com mutação homozigota neste gene apresentam baixos números de linfócitos $B$ de memória $\left(\mathrm{CD} 19^{+} \mathrm{CD} 27^{+} \mathrm{IgM} \mathrm{gM}^{-}\right)$e são mais susceptíveis a infecções por bactérias encapsuladas (Kopecky e Kukissova, 2007). Os baixos níveis de imunoglobulinas IgA e lgG em indivíduos deficientes em TACI podem ser devido a uma ineficiente troca de classe em linfócitos B (Castigli et al, 2005).

Pacientes com CVID que apresentam mutações homozigotas no gene CD19, possuem números normais de linfócitos $\mathrm{B}$, mas uma expressão diminuída ou indetectável da molécula de superfície CD19. Essas mutações são responsáveis pela deleção parcial ou total do domínio citoplasmático desta molécula (Van Zelm et al, 2006).

As moléculas CD19 e CD22 formam um complexo com a IgM de superfície do linfócito B e são responsáveis pela transdução de sinal nesta célula após reconhecimento do antígeno (Fujimoto et al, 1999). Considerando que o domínio citoplasmático da molécula CD19 participa nesta sinalização, uma resposta imune ineficiente observada nos pacientes com CVID portadores desta mutação pode ser resultado da perda do reconhecimento do antígeno via BCR (Van Zelm et al, 2006).

Em relação ao sistema imune inato, observam-se deficiências na maturação de células dendríticas, baixa expressão de moléculas co-estimulatórias tais como CD80 e CD86, baixa capacidade de ativação e proliferação de células T e produção deficiente de IL-12 (Bayry et al, 2004; Scott et al, 2006). Uma vez que as células dendríticas regulam o crescimento de células $B$, a secreção de imunoglobulinas, troca de isotipo de imunoglobulina e diferenciação em plasmócitos, sugere-se que células dendríticas prejudicadas podem comprometer a geração de uma resposta imune humoral eficiente.

Números reduzidos de células NK (natural killer) também foram observados em pacientes com CVID (Aspalter et al, 2000). As células NK são caracterizadas 
fenotipicamente como $\mathrm{CD}^{+} 6^{+} \mathrm{CD} 16^{+} \mathrm{CD} 3^{-}$e são componentes importantes do sistema imune inato, principalmente contra células tumorais e infecções virais.

Pacientes com CVID também podem apresentam anormalidades em relação as células T. Estas anormalidades incluem a geração de células $T$ naïve no timo (Guazzi et al, 2002), diminuição de ativação e proliferação de células T e sinalização prejudicada via TCR (Boncristiano et al, 2000), redução na geração de células T de memória (Kondratenko et al, 1997), menor expressão de moléculas coestimulatórias como CD40L (Farrington et al, 1994).

No entanto, dentre todas as células do sistema imune, os linfócitos B são as células mais frequentemente comprometidas nos pacientes com CVID.

A maioria dos estudos envolve a análise de linfócitos $B$ de memória, especialmente porque pacientes com CVID tem uma resposta imune humoral prejudicada com histórico de infecções recidivantes (Warnatz, 2002; Piqueras et al, 2003; Wehr et al, 2008).

Estes linfócitos são caracterizados pela expressão do marcador CD27, e podem ser classificados da seguinte maneira: linfócitos $B \operatorname{lgD}{ }^{-} C D 27^{+}$os quais podem secretar as imunoglobulinas IgG, IgM ou IgA (linfócitos B de memória com troca de isotipo) e os linfócitos $B \operatorname{lgD}{ }^{+} C D 27^{+}$os quais produzem predominantemente $\operatorname{lgM}$ (linfócitos B de memória sem troca de isotipo) (Agematsu et al, 1997).

Estes estudos tem mostrado a presença de quantidades diminuídas de linfócitos B de memória em um subgrupo de pacientes com CVID quando comparado com indivíduos saudáveis. Sendo assim, alguns grupos tem utilizado células $B$ de memória na tentativa de classificar estes pacientes e correlacioná-los com características clínicas da doença. Estas classificações foram denominadas de classificação de Freiburg (Warnatz, 2002) e classificação de Paris (Piqueras et al, 2003).

Essas análises tem associado a presença de uma menor quantidade de células $\mathrm{B}$ de memória $\operatorname{IgD}^{-} \mathrm{CD}_{2} 7^{+}(<0,4 \%)$ em pacientes com CVID com o desenvolvimento de auto-imunidade, esplenomegalia e doença granulomatosa.

Pacientes com CVID podem apresentar números normais de linfócitos B no sangue periférico, mas estudos relatam que estes linfócitos podem não se diferenciar em plasmócitos, sendo incapazes de produzir imunoglobulinas em quantidades equivalentes às encontradas nos soros de indivíduos saudáveis (Saxon et al, 1992; Castigli et al, 2005; Salzer et al, 2005). 
A diferenciação terminal de linfócitos $B$ em plasmócitos resulta em um estresse do retículo endoplasmático, o qual leva a ativação de uma via de dobramento de proteínas chamada UPR - Unfolded Protein Response.

Um recente estudo de nosso grupo mostrou uma desregulação em um dos braços desta via em uma paciente com CVID, que apresentava baixas quantidades da forma ativa do fator de transcrição XBP1 (XBP1 spliced). Além disso, foi observado através de microscopia confocal que as imunoglobulinas IgM desta paciente estavam co-localizadas no retículo endoplasmático, não sendo exportadas para a superfície, sugerindo uma contribuição para a hipogamaglobulinemia apresentada pela paciente (Kuribayashi et al, 2008).

\subsection{Estresse do retículo endoplasmático e via UPR}

O estresse do retículo endoplasmático (RE) é causado por várias condições fisiológicas que alteram a homeostasia do retículo tais como um desbalanço de cálcio (Suzuki et al, 1991), níveis diminuídos de glicose (Ritter e Helenius, 2000), isquemia tecidual (Glembotski, 2008), infecções virais (Tardif et al, 2002), mutações que alteram proteínas (Ryu et al, 2002) e na diferenciação terminal de linfócitos $B$ em plasmócitos (Reimold 1996).

Sob estresse, o RE ativa a via UPR com a finalidade de aumentar a eliminação de proteínas mal-dobradas (Travers, 2000). Uma vez ativada, a via UPR funciona através dos seguintes mecanismos: 1- Aumento da transcrição de chaperonas (como GRP78 e GRP94) com a finalidade de melhorar o dobramento de proteínas, 2- Diminuição da tradução de proteínas de modo que a carga protéica no retículo seja atenuada, 3- Aumento da degradação de proteínas mal-dobradas ou desdobradas via ERAD (ER-associated degradation), de forma que estas proteínas sejam exportadas para o citosol e degradadas via proteassoma. Contudo, se esses mecanismos não conseguirem restaurar a homeostasia no retículo endoplasmático, o programa apoptótico é ativado (Werner et al,1996; Harding et al,1999).

Análises da via UPR iniciaram-se no fim dos anos 80 quando foi verificado que o acúmulo de proteínas não dobradas no retículo endoplasmático induzia a expressão das chaperonas GRP78 e GRP94 (Hendershot, 1988; Kozutsumi et al, 
1988). O uso da levedura Saccharomyces cerevisae como modelo de estudo da via UPR levou a uma maior compreensão dos mecanismos moleculares desta via (Cox et al, 1993; Mori et al, 1996).

Em leveduras a via UPR apresenta apenas um braço de sinalização mediado pela IRE1p, uma proteína transmembrana serina/treonina quinase que está presente na membrana do RE e apresenta um domínio amino-terminal no lumen do RE e um domínio carboxi-terminal no citoplasma (Cox et al, 1993). Ao ser ativada ela faz a clivagem endonucleolítica do RNAm de Hac1p, e gera um fator de transcrição que vai até o núcleo e se liga ao elemento de resposta a proteína nao dobrada (UPRE) (Mori et al, 1996).

Em vertebrados, diferentemente de leveduras, a presença de estresse é detectada por três proteínas transmembrana do RE: PERK (PKR-like ER kinase), ATF6 (Activating transcription factor) e IRE-1 (Inositol-requiring enzyme1). Sob condições de estresse cada uma destas proteínas inicia diferentes mecanismos de regulação (Rutkowski e Kaufman, 2004) (figura 2). 


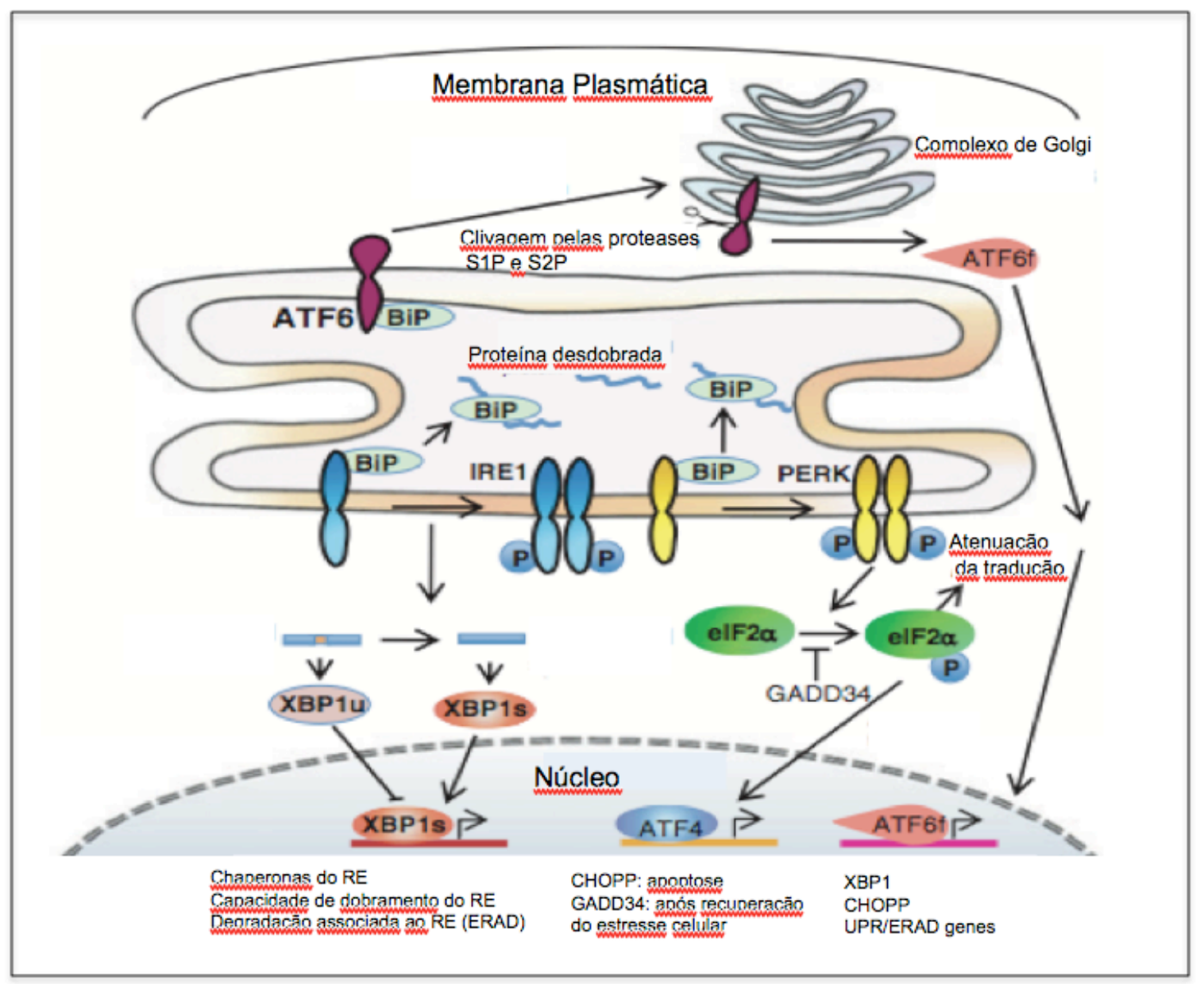

Figura 2: Via de sinalização em reposta a proteínas desdobradas no retículo endoplasmático (via UPR). As proteínas transmembrana IRE1, PERK e ATF6 após se desligarem da BiP tornam-se ativadas e vão induzir a transcrição de genes responsáveis pelo aumento da produção de chaperonas, diminuição da carga de proteínas e pela melhora na capacidade de degradação associada ao retículo (ERAD).

Fonte: Adaptado de Costa 2011.

Estas proteínas estão associadas à chaperona BiP (Binding Protein). No entanto, quando ocorre um aumento de proteínas mal-dobradas ou desdobradas, a BiP se desliga de PERK, ATF6, IRE1 e associa-se a essas proteínas não dobradas facilitando o seu dobramento (Rutkowski e Kaufman, 2004).

A BiP é membro da família das proteínas de choque térmico Hsp70 e apresenta dois domínios funcionais: uma porção N-terminal ATPase e outra Cterminal de ligação a peptídeos. É considerada a principal chaperona do RE (Hendershot, 2004). 
As chaperonas desempenham papel importante no RE pois são responsáveis pelo dobramento das proteínas recém-sintetizadas no lúmen do retículo, de forma que sejam exportadas para o citosol apenas as proteínas com a sua conformação correta. Várias chaperonas e co-chaperonas desempenham esta função (GRP78/BiP, GRP94, GRP170/ORP150, PDI, ERp72, UGGT entre outras) (Meunier et al, 2002).

A PERK é uma proteína serina/treonina quinase transmembrana que após sofrer oligomerização e auto-fosforilação, fosforila a subunidade alfa do fator de iniciação de tradução 2 (elF2 $\alpha$ ), o que resulta na diminuição da tradução da maioria dos RNAm (Harding 1999). No entanto, há uma tradução seletiva do mRNA de ATF4 (activating transcription factor 4), membro da família CREB (cAMP responseelement-binding) de fatores de transcrição.

O ATF4 requer a fosforilação do elF2a para sua tradução e é essencial para induzir a transcrição da molécula GADD34 (growth-arrest DNA-damage gene 34), uma proteína citosólica que associa-se a proteína fosfatase 1 (PP1) que por sua vez desfosforila elF2 $\alpha$ e promove o recomeço da síntese protéica. O ATF4 também induz a síntese do fator CHOP (C/EBP homologous protein), um fator de transcrição que está relacionado a apoptose caso as células sejam expostas a um estresse crônico do RE (Boyce et al, 2006)

Dessa forma, como em qualquer outra via de sinalização, a via UPR requer mecanismos de feedback negativo para assegurar que a via não seja hiperativada. Um dos mecanismos ocorre através da molécula GADD34 que reinicia a síntese protéica após algumas horas de estresse do RE. Portanto a via de sinalização da PERK atua tanto na sobrevivência quanto na morte celular (Gass et al, 2004).

O ATF6 é um fator de transcrição que contém um domínio bZIP no citosol e um domínio sinalizador de estresse do RE voltado para o lúmen do RE. Após o desligamento da BiP do seu domínio luminal, o ATF6 vai até o Complexo de Golgi e sofre clivagem proteolítica pelas proteases sítio 1 e sítio 2 (S1P e S2P). O fragmento gerado, ATF6f, vai até o núcleo e induz a expressão de vários genes da via UPR como BIP/GRP78, GRP94, calnexina , CHOP e o fator de transcrição XBP1 (Haze et al, 1999; Yoshida et al, 2000; Zhang et al, 2006).

A IRE-1 é uma proteína transmembrana cujo domínio amino-terminal se localiza no lúmen do RE e a porção carboxi-terminal se estende pelo citoplasma ou nucleoplasma. A porção C-terminal é composta por um domínio serina/treonina 
quinase e um domínio endonuclease (RNase) sitio-específico. Diferentemente da IRE-1p de leveduras, a IRE-1 em vertebrados é constituída pela IRE-1 $\alpha$ e IRE-1 $\beta$. A IRE-1 $\alpha$ é expressa na maioria das células enquanto que a IRE $\beta$ tem sua expressão restrita a células epiteliais intestinais (Yoshida, 2001).

Depois de se desligar da BiP, a IRE-1 sofre oligomerização e autofosforilação, ativa o seu domínio endonuclease que faz a clivagem sítio-específica do RNAm de XBP1, produzindo um RNAm de XBP1 processado (spliced, sXBP1) que gera uma proteína com domínio C-terminal de 226 aminoácidos (Yoshida, 2001; Calfon et al, 2002). A IRE-1 também pode induzir a apoptose uma vez que recruta e ativa a caspase 12 (Nakagawa et al, 2000).

O XBP-1 apresenta as formas processada (spliced) e não-processada (unspliced) que possuem peso molecular de 60 e $30 \mathrm{KDa}$, respectivamente. A presença da forma spliced de XBP-1 representa a ativação da via UPR, sendo considerado o principal fator de transcrição responsável pela indução da expressão genes alvos da via UPR (Yoshida 2001). Ele ativa a transcrição de chaperonas (BIP/GRP78, GRP94, Calnexina, ERdj3, ERdj4) e induz a transcrição de outros genes relacionados a degradação de proteínas (EDEM)(Yoshida et al, 2003, 2006).

O XBP1 tem sido relacionado com o processo de diferenciação terminal de linfócitos B em plasmócitos. A geração da forma ativa do XBP-1 spliced e ativação da via UPR ocorrem como um mecanismo do RE para suportar a produção de grandes quantidades de anticorpos. Sendo assim, o XBP-1 é considerado o único fator de transcrição essencial no processo de diferenciação em plasmócitos (Yoshida et al, 2003).

Estudos com camundongos $\mathrm{XBP} 1^{-/-}$mostraram que eles morrem no útero devido a uma hematopoiese diminuída no fígado resultando em morte por anemia (Reimold et al, 2000).

A correlação entre ativação da via UPR e diferenciação terminal de linfócitos $B$ foi realizada utilizando células $\mathrm{CH} 12$ de linfoma de células $\mathrm{B}$ de camundongos. $\mathrm{A}$ cinética de expressão e secreção de lg durante o processo de diferenciação induzida por LPS foi determinada pela análise das cadeias pesada e leve das imunoglobulinas. Além disso, também foi determinada a cinética de indução de transcritos de XBP1 e das chaperonas BiP e GRP94, todos sabidamente regulados pela via UPR e expressos em altos níveis durante a diferenciação de linfócitos $B$ (Gass et al, 2002). 
Os resultados mostraram a indução dos genes alvos da via UPR previamente à tradução das cadeias de imunoglobulinas, o que poderia sugerir a presença de outros sinais de ativação da via UPR no processo de diferenciação de linfócitos B em plasmócitos (Gass et al, 2002).

O mecanismo de regulação da via UPR mais aceito é o mediado pela chaperona BiP. Neste caso, em condições normais a BiP está associada ao domínio luminal das proteínas transmembrana IRE-1, PERK e ATF6. Com o acúmulo de proteínas desdobradas no lúmen do $\mathrm{RE}$, a $\mathrm{BiP}$ se desliga das proteínas transmembrana e associa-se preferencialmente à proteínas desdobradas, liberando a IRE-1, PERK e ATF6 e tornando-as ativadas (Lee, 2005) (figura 2).

Outros modelos de regulação tem sido propostos. Um deles propõe que proteínas maldobradas/desdobradas liguem-se ao domínio luminal da IRE-1 e promovam sua dimerização e ativação (Creddle et al, 2005).

E um terceiro modelo propõe que a dissociação da BiP da IRE1 leve a sua oligomerização e que a ligação de proteínas maldobradas/desdobradas no lúmen do RE seja capaz de causar a ativação das funções efetoras da IRE1 (Kimata et al, 2007).

Caso a via UPR não seja capaz de resolver o estresse do RE, inicia-se um programa de apoptose mediado pela PERK/CHOP, caspase 12 e IRE-1. A proteína CHOP promove a apoptose ao induzir genes envolvidos na apoptose como ERO1, DR5 e anidrase carbônica IV (Zinszner et al, 1998), além de reprimir a transcrição da proteína anti-apoptótica Bcl2 (McCullough et al, 2001).

A caspase 12 é uma das iniciadoras da cascata das caspases. é ativada pela calpaina, que é induzida e ativada pelo cálcio durante o estresse do RE. Após ser ativada, a caspase 12 ativa as caspases efetoras 3, 7 e 9 levando a apoptose (Tan et al, 2006).

A IRE-1 por sua vez induz a apoptose ao interagir com a proteína adaptadora TRAF2 e recrutando ASK1 (apoptosis signaling kinase 1). Em seguida a ASK1 ativa a JNK, que ativa o fator pro-apoptótico Bim e inibe o fator anti-apoptotico Bcl2 (Nakagawa et al, 2000).

Dessa forma, a via UPR age através de dois mecanismos. Inicialmente tentando restaurar a homeostasia do RE, mas caso este não seja suficiente, a via inicia um programa apoptótico evitando que proteínas não funcionais sejam exportadas do RE, o que poderia ser prejudicial para célula. 


\subsection{CVID e via UPR}

A identificação prévia de uma paciente com CVID com desregulação da via UPR devido aos baixos níveis do fator de transcrição XBP1 spliced, essencial na diferenciação terminal de linfócitos B em plasmócitos, nos propõe a investigar essa via de sinalização em indivíduos normais e em outros pacientes com CVID.

Além disso, a presença de baixas quantidades de anticorpos circulantes no sangue periférico de pacientes com CVID nos propõe a analisar o perfil de maturação de linfócitos B nestes pacientes. Seria plausível que a maturação defeituosa destas células possa contribuir para o quadro de hipogamaglobulinemia dos pacientes. 


\section{OBJETIVOS}

1- Analisar a curva de produção das proteínas IRE1 após estresse por LPS.

2- Determinar a cinética de ação do LPS para se determinar qual o limite tolerável de estresse que células saudáveis e de pacientes com CVID conseguem gerenciar com a ativação da via UPR.

3- Analisar a expressão de diversos marcadores de desenvolvimento de linfócitos B em células em repouso e induzidas a diferenciação terminal por LPS. 


\section{MATERIAIS E MÉTODOS}

\subsection{Materiais}

Os pacientes envolvidos no projeto foram diagnosticados como portadores da CVID segundo critérios estabelecidos pelo PanAmerican Group for Immunodeficiencies (www.pagid.de). Foram excluídos os pacientes portadores de HIV e/ou HCV.

O tratamento está sob responsabilidade da doutora Cristina Kokron (Hospital das Clínicas, Faculdade de Medicina, Universidade de São Paulo).

O grupo controle foi constituído de pessoas maiores de 18 anos que não apresentaram nenhuma imunodeficiência e que não eram portadores de HIV e/ou $\mathrm{HCV}$.

O sangue do paciente foi coletado no laboratório de Imunologia Clínica e Alergia da Faculdade de Medicina da Universidade de São Paulo mediante a autorização do paciente através do Termo de Consentimento Livre e Esclarecido (Parecer 892/CEP) e previamente ao recebimento de gamaglobulina humana endovenosa.

\subsection{Métodos}

\subsubsection{Separação de linfócitos B por RosetteSep}

Foi adicionado $50 \mu$ de RosetteSep Human B Cell Enrichment Cocktail (Stem Cell Technologies - Vancouver, Canada) por $\mathrm{ml}$ de sangue total. Seguiu-se incubação de 20 minutos a temperatura ambiente. O sangue foi diluído em partes iguais com PBS contendo $2 \%$ de Soro Bovino Fetal (SBF) (Invitrogen Corporation Carlsbad, CA, EUA) e misturado gentilmente. Essa mistura foi colocada cuidadosamente sobre o Ficoll-Paque (GE Healthcare - Uppsala, Suécia) e centrifugada por 20 minutos a $1200 \mathrm{xg}$ a temperatura ambiente. $\mathrm{O}$ anel contendo os linfócitos $B$ foi retirado. Duas lavagens sucessivas foram feitas com PBS $2 \%$ SBF. $O$ precipitado de células B foi colocado em meio de cultura RPMI (Invitrogen) e as células foram quantificadas e a viabilidade verificada pela utilização de Azul de Trypan (Cambrex Bio Science - Walkersville, MD, EUA). 


\subsubsection{Extração do RNA e proteínas}

Células tratadas e não tratadas com lipopolissacarídeo derivado de E.coli (LPS) (Sigma-Aldrich Co - St.Louis, MO, EUA) foram submetidas a extração de RNA total e separação de proteínas segundo o kit PARIS (Protein $\underline{\text { And }} \underline{\mathrm{R} N A}$ Isolation System, - Ambion - Austin, Texas).

As células foram inicialmente centrifugadas a $300 \mathrm{xg}$ por 10 minutos para retirada do meio de cultura. Em seguida, foram lavadas com $1 \mathrm{ml}$ de PBS nas mesmas condições. Ao precipitado foi adicionado $150 \mu \mathrm{L}$ de tampão de fracionamento gelado e as células foram mantidas no gelo por 10 minutos. Seguiuse centrifugação $\left(500 \mathrm{xg}, 5 \mathrm{~min}, 4^{\circ} \mathrm{C}\right.$ ) para separar as frações citoplasmáticas e nucleares. O sobrenadante foi transferido para outro tubo correspondendo a fração citoplasmática e ao precipitado que corresponde a fração nuclear foi adicionado 150 $\mu \mathrm{L}$ de tampão de lise. Essas frações protéicas foram separadas para a técnica de Western Blotting. Foi utilizado $25 \mu \mathrm{L}$ de cada fração (citoplasmática e nuclear) para o isolamento de RNA. À mistura das duas frações foi adicionado o mesmo volume de 2X Lysis/Binding Solution (Ambion). Em seguida foi colocado o equivalente ao volume de lisado de etanol $100 \%$. Essa mistura foi colocada sobre uma coluna com filtro e centrifugada a $13000 \mathrm{xg}$ por 1 minuto. Lavagens subsequentes foram feitas com solução de lavagem na mesma velocidade e tempo de centrifugação. Na última etapa o filtro foi colocado em outro tubo e $40 \mu \mathrm{L}$ de solução de eluição previamente aquecida $\left(95^{\circ} \mathrm{C}\right)$ foi adicionada ao filtro. O RNA total foi obtido após centrifugação de 13000 xg por 1 minuto. A concentração de cada amostra foi determinada pela leitura da densidade óptica no espectrofotômetro GeneQuant pro (GE Healthcare).

\subsubsection{Preparação do cDNA complementar}

O cDNA foi obtido através do uso do kit High Capacity RNA to cDNA (Applied Biosystems - Carlsbad, CA, EUA). Foi preparado um mix contendo por amostra: 10 $\mu l$ de tampão 2X RT e $1 \mu l$ de enzima mix 20X RT e água livre de DNase e RNase em quantidade suficiente para $20 \mu \mathrm{l}$. Para a reação foram utilizados $9 \mu \mathrm{l}$ do RNA em estudo e o mix previamente descrito totalizando $20 \mu \mathrm{l}$ por reação. As amostras foram submetidas as seguintes tempertaturas no termociclador: $37^{\circ} \mathrm{C}$ por 60 minutos e 95 ${ }^{\circ} \mathrm{C}$ por 5 minutos. 


\subsubsection{Reação em cadeia da polimerase (PCR) em tempo real (QPCR)}

Os cDNAs foram amplificados para BiP, IRE-1, XBP1 e GAPDH utilizando o termociclador Mx3005P ${ }^{\mathrm{TM}}$ QPCR Systems (Stratagene, Cedar Creek, TX, EUA). As reações foram realizadas utilizando o kit Fast SYBR Green Master Mix (Applied Biosystems).

Foi preparado um mix contendo $10 \mu \mathrm{l}$ de Fast SYBR e $1 \mu \mathrm{l}$ de primer forward e $1 \mu \mathrm{l}$ de primer reverse (ambos da Invitrogen) e água livre de DNase e RNase em quantidade suficiente para $18 \mu$ l. Essa mistura foi colocada em microtubos contendo $2 \mu \mathrm{l}$ de cDNA. As reações foram submetidas a 40 ciclos de amplificação como descrito a seguir: $20 \mathrm{~s}$ a $95^{\circ} \mathrm{C}, 3 \mathrm{~s}$ a $95^{\circ} \mathrm{C}$ e $30 \mathrm{~s}$ a $59^{\circ} \mathrm{C}$. Todas as reações foram submetidas a um passo final de $1 \mathrm{~min}$ a $95^{\circ} \mathrm{C}, 30 \mathrm{~s}$ a $55^{\circ} \mathrm{C}$ e $30 \mathrm{~s}$ a $95^{\circ} \mathrm{C}$ para a geração da curva de dissociação.

Os dados foram analisados no programa MxPro ${ }^{\mathrm{TM}}$ QPCR Software (Stratagene). A quantificação relativa dos produtos foi calculada pelo método $2^{-} \mathrm{Ct}$ (Livak et al, 2001) e foi utilizado o gene gapdh como gene housekeeping.

As sequencias dos oligonucleotídeos utilizados estão no quadro 1.

Quadro 1 - Oligonucleotídeos utilizados nas reações em cadeia da polimerase (PCR)

\begin{tabular}{|c|c|}
\hline Nome & Sequência \\
\hline F-XBP1 spliced & 5 - GAGTCCGCAGCAGGTG - 3 \\
\hline $\mathrm{R}-\mathrm{XBP} 1$ spliced & 5 - GGGCTTGGTATATATGTGG - 3 \\
\hline $\mathrm{F}-\mathrm{BiP}$ & 5 - CGAGGAGGAGGACAAGAAGG - 3 \\
\hline $\mathrm{R}-\mathrm{BiP}$ & 5 - CACCTTGAACGGCAAGAACT - 3 \\
\hline $\mathrm{F}-\mathrm{IRE} 1 \alpha$ & 5 - CGGCCTTTGCAGATAGTCTC - 3 \\
\hline$R-\operatorname{IRE} 1 \alpha$ & 5 - ACGTCCCCAGATTCACTGTC - 3 \\
\hline F-GAPDH & 5 - ACCACAGTCCATGCCATCAC - 3 \\
\hline R - GAPDH & 5 - TCCACCACCCTGTTGCTGTA - 3 \\
\hline
\end{tabular}

\subsubsection{Ensaio de estresse celular}

As células $B$ pacientes com CVID e de indivíduos saudáveis foram cultivadas em meio RPMI suplementado com 10\% de SBF (Invitrogen), 2 mM de Lglutamina (Invitrogen), $100 \mathrm{U} / \mathrm{ml}$ penicilina (Invitrogen) e 0,1 $\mathrm{mg} / \mathrm{ml}$ de estreptomicina (Invitrogen) e mantidas em estufa a $37^{\circ} \mathrm{C}$ e $5 \% \mathrm{CO}_{2}$.

Essas células tratadas e não tratadas com LPS $(10 \mu \mathrm{g} / \mathrm{ml})$ foram submetidas 
a uma cinética de 3 pontos (zero, 12 h e 24 h).

Após o período de incubação, as células foram centrifugadas a $300 \mathrm{xg}$ por 10 minutos a temperatura ambiente e ressuspendidas em PBS para posterior isolamento de RNA.

\subsubsection{Caracterização dos linfócitos $B$ de sangue periférico}

Inicialmente foi realizada a calibração do citômetro de fluxo (FACS Canto II BD Biosciences - San Jose, CA, EUA), com beads de calibração presentes no kit BD FACS ${ }^{T M}$ 7-Colors Setup Beads (BD Biosciences), de modo que o equipamento pudesse reconhecer cada fluorocromo que seria posteriormente utilizado na análise das amostras em estudo.

Foram utilizadas alíquotas de $100 \mathrm{uL}$ de sangue periférico de 9 indivíduos saudáveis com idades entre 23 a 57 anos e de 16 pacientes com CVID com idades entre 23 a 77 anos. Estas amostras foram incubadas com anticorpos monoclonais anti-CD23, anti-CD5, anti-CD19, anti-CD45, anti-CD38, anti-FMC7 presentes no kit

BD Oncomark ${ }^{\mathrm{TM}}$ (BD Biosciences) durante 30 minutos a $4{ }^{\circ} \mathrm{C}$ e protegidas da luz (quadro 2).

Em seguida foram efetuadas duas lavagens em PBS contendo $1 \%$ de SBF (Invitrogen). As células foram ressuspendidas em $500 \mu \mathrm{l}$ desta mesma solução, filtradas e submetidas à leitura no citômetro de fluxo e os dados obtidos foram analisados no software FlowJo (Tree Star, Inc. - Ashland, OR, EUA).

Para cada amostra marcada com os anticorpos monoclonais foi utilizada uma amostra não marcada para que fosse possível avaliar a viabilidade e distribuição das populações celulares. As amostras de pacientes foram pareadas com amostras de indivíduos saudáveis de mesmo sexo e preferencialmente de mesma idade. 
Quadro 2: Anticorpos monoclonais presentes no kit BD Oncomark ${ }^{\mathrm{TM}}$ (BD Biosciences) e os locais de expressão das respectivas moléculas na superfície celular.

\begin{tabular}{|l|l|}
\hline Anticorpos Monoclonais & Local de Expressão \\
\hline FMC7 - FITC & Na maioria dos linfócitos B maduros \\
\hline CD23 - PE & Nos linfócitos B maduros, em maiores níveis nos ativados \\
\hline CD5 - PerCP-Cy7 & Na maioria dos linfócitos T e na supopulação de linfócitos B1 \\
\hline CD19 - PE-Cy7 & Nos linfócitos B em todos os estágios de maturação \\
\hline CD38 - APC & Nos estágios iniciais de maturação de linfócitos T e B \\
\hline CD45 - APC-Cy7 & Em todos os leucócitos \\
\hline
\end{tabular}

\subsubsection{Imortalização dos linfócitos B}

A imortalização dos linfócitos $B$ já foi realizada de acordo com o protocolo já estabelecido (Middleton, 1991) pela equipe da Profa. Dra. Luiza Guilherme Guglielmi do Laboratório de Imunologia do Instituto do Coração do Hospital das Clínicas da Faculdade de Medicina da Universidade de São Paulo. As células do paciente em estudo e de um controle saudável encontram-se armazenadas no Laboratório de Imunorregulação Molecular, onde este projeto foi desenvolvido.

Foram adicionadas $10^{7}$ células mononucleares do sangue periférico em $2,5 \mathrm{ml}$ de meio RPMI-10 (Invitrogen) completo e 2,5 ml de sobrenadante com vírus EpsteinBarr (EBV) gentilmente cedido pela Profa. Dra. Luiza Guilherme Guglielmi. Incubouse por 2 horas em banho-maria a $37^{\circ} \mathrm{C}$. Em seguida, $5 \mathrm{ml}$ de RPMl-10 (Invitrogen) contendo $10 \%$ de SBF, $2 \mathrm{mM}$ de L-glutamina e $1 \mu \mathrm{g} / \mathrm{ml}$ de ciclosporina A foram adicionados. $\mathrm{O}$ volume final de $10 \mathrm{ml}$ foi transferido para uma garrafa de cultura. Incubou-se a $37^{\circ} \mathrm{C}, 5 \% \mathrm{CO} 2$ por três semanas.

Após este período, o meio tornou-se ácido e as células formaram grumos macroscópicos. Ao microscópio várias células pareceram grandes, claras e tendendo a formar grumos de tamanhos variados. O repique das células foi feito a cada três dias com meio RPMI ou DMEM Advanced (Invitrogen) com 10\% SBF (Invitrogen), $100 \mathrm{U} / \mathrm{ml}$ penicilina e 0,1 mg/ml de estreptomicina (Invitrogen) e $2 \mathrm{mM}$ de Lglutamina (Invitrogen). 


\section{RESULTADOS E DISCUSSÃO}

\subsection{Fenotipagem de linfócitos B}

Considerando que anteriormente nosso grupo identificou uma paciente com CVID cuja análise de microscopia confocal revelou a presença de linfócitos $B$ maiores na circulação periférica, que poderia sugerir serem células mais imaturas (Kuribayashi et al, 2008), nos propusemos a avaliar se pacientes com CVID poderiam apresentar linfócitos $B$ imaturos no sangue periférico que pudessem contribuir para o quadro de hipogamaglobulinemia destes pacientes.

Nossa avaliação foi realizada pela análise da expressão de vários marcadores de superfície celular de linfócitos B ao longo do seu processo de maturação (quadro 2). Uma vez que a expressão destes marcadores é variável durante este processo, é possível classificar as células em diferentes fases de maturação (figura 5).

Os estágios I, II e III representam estágios imaturos ou transicionais, e o estágio IV representa o último estágio de maturação, correspondendo a células $B$ maduras. Este estágio se caracteriza especialmente pela perda do marcador de fase imatura CD38 e pelo início da expressão do marcador de células maduras CD23. 


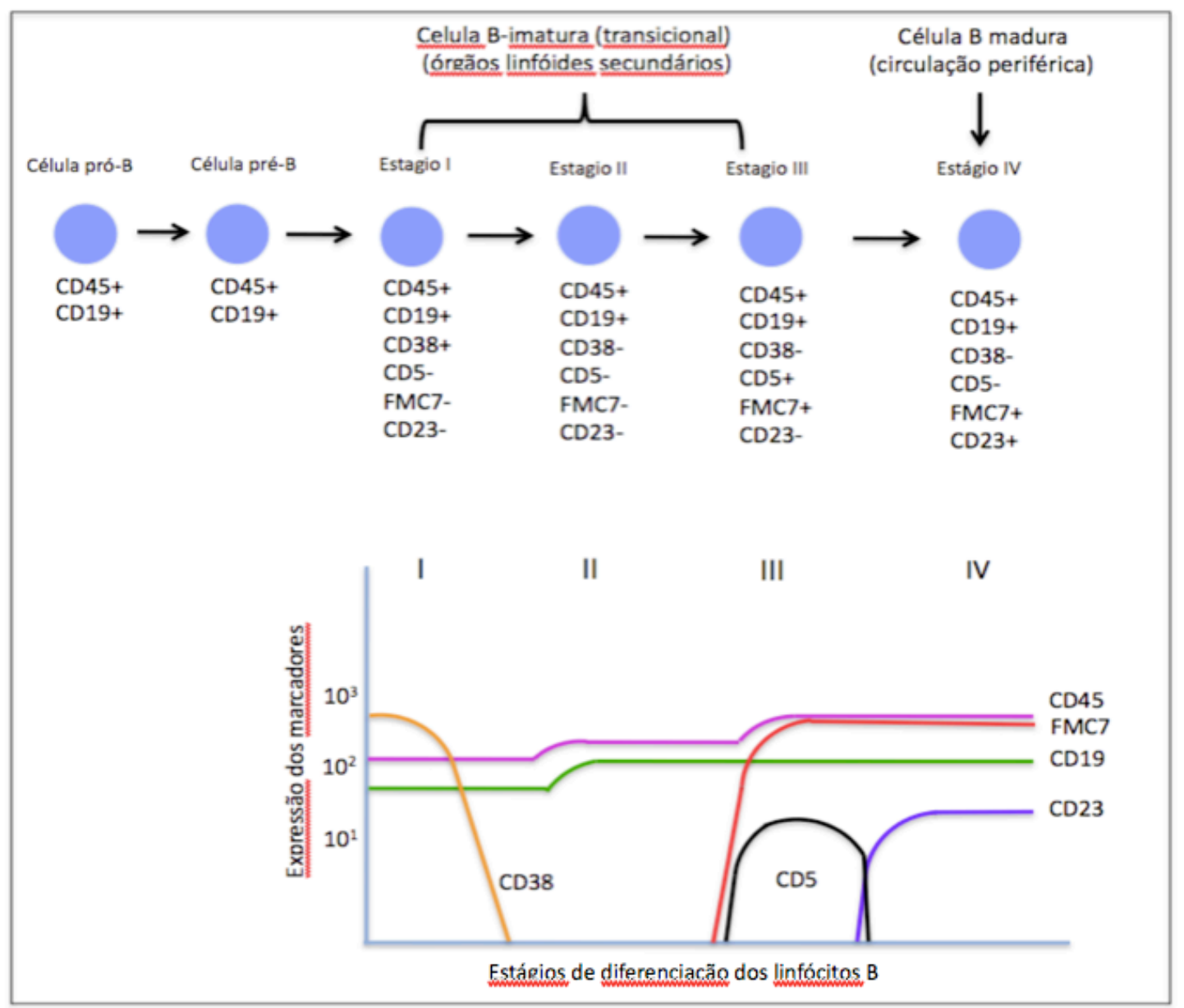

Figura 5: Representação esquemática dos estágios de diferenciação dos linfócitos $\mathrm{B}$, de acordo com a variação na expressão dos marcadores de superfície celular utilizados neste estudo.

Após a aquisição das amostras de pacientes com CVID e de indivíduos saudáveis no citômetro de fluxo FACS Canto II, as análises foram realizadas no programa FlowJo. Uma estratégia de gating foi criada de modo que fosse possível identificar as populações de linfócitos B nas diferentes fases de maturação (I, II, III e IV) (Figura 6). 

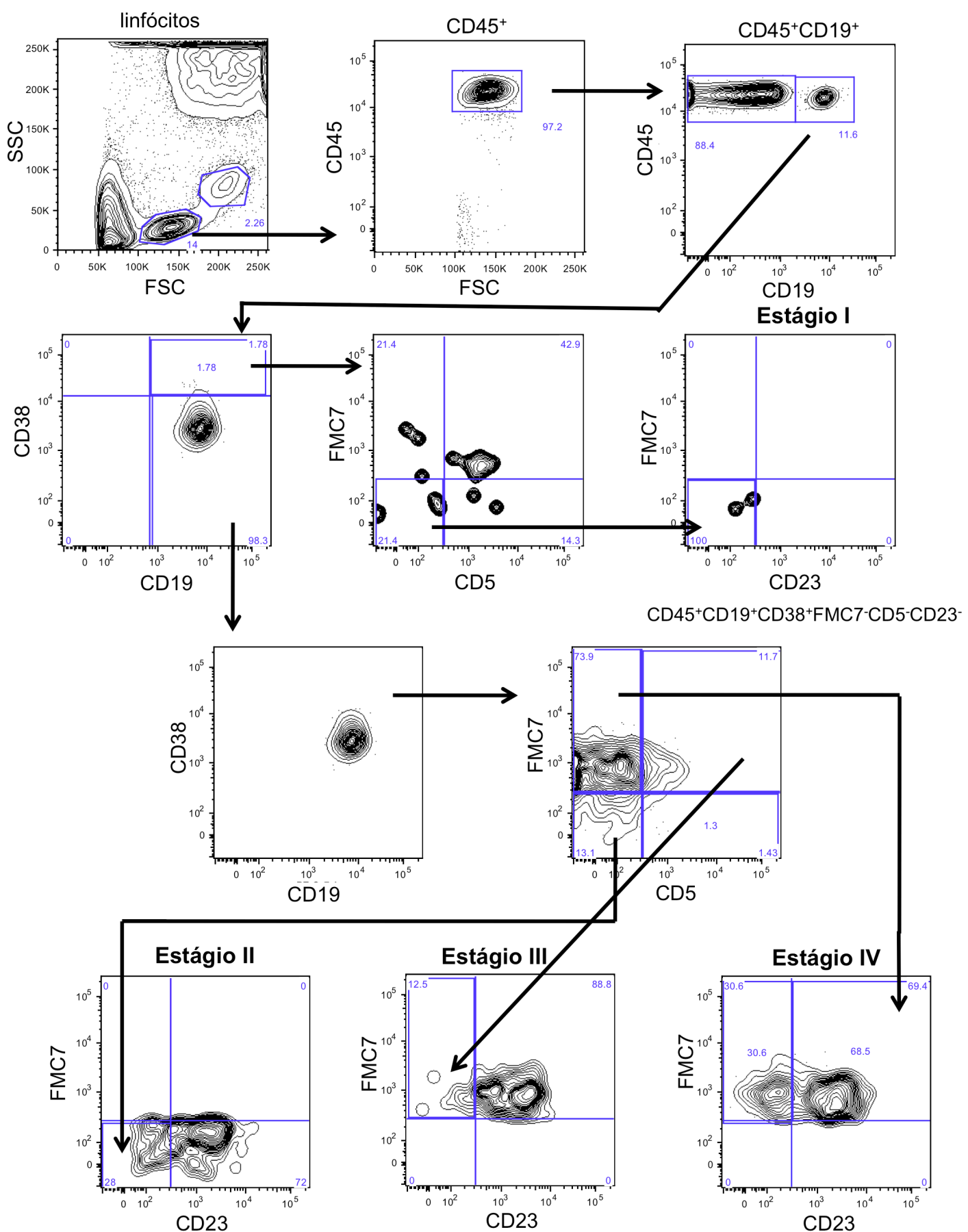

CD45 ${ }^{+}$CD $19{ }^{+}$CD 38-FMC7-CD5-CD23-

CD $45^{+} \mathrm{CD} 19^{+} \mathrm{CD} 38-\mathrm{FMC}{ }^{+}{ }^{\mathrm{CD}}{ }^{+\mathrm{CD}} 23-$

23- $\mathrm{CD}^{2} 5^{+} \mathrm{CD} 19^{+} \mathrm{CD} 38-\mathrm{FMC7}{ }^{+} \mathrm{CD} 5-\mathrm{CD} 23^{+}$

Figura 6: Estratégia de gating utilizada neste estudo. O primeiro quadro mostra a separação das populações de acordo com os parâmetros de tamanho e granulosidade. As populações de linfócitos B foram separadas baseadas nos marcadores (CD45, CD19, CD38, FMC7, CD5 e CD23). 
Uma população negativa (controle negativo de marcadores) foi definida a partir de um gate em monócitos por se tratar de células que não expressam os marcadores utilizados na classificação dos diferentes estágios de maturação (CD5/FMC7/CD38/CD23).

Em seguida foi feito um gate na região contendo os linfócitos a partir do gráfico de tamanho versus granulosidade (FSC $\times \mathrm{SSC}$ ). As células $\mathrm{CD} 45^{+} \mathrm{CD} 19^{+}$ representam os linfócitos $B$, uma vez que o marcador CD45 está presente em todos os leucócitos mas o CD19 é exclusivo de linfócitos B .

Essa população celular $\left(C D 45^{+} \mathrm{CD} 19^{+}\right)$consistiu na população de interesse e a partir dela as demais análises foram realizadas (figura 6). Inicialmente a população $\mathrm{CD} 45^{+} \mathrm{CD} 19^{+}$foi analisada com o marcador CD38, de modo que foram identificadas células $\mathrm{CD}^{+} 8^{+}$e CD38-

O CD38 é uma molécula expressa na superfície celular dos linfócitos $B$ nos estágios iniciais de sua maturação, sendo assim, a população $\mathrm{CD} 38^{+}$consistiu nas células mais imaturas desta análise.

Em seguida, a população $\mathrm{CD} 8^{+}$foi analisada com os marcadores $\mathrm{FMC7}$ e CD5. A população de células negativa para esses dois marcadores foi separada e analisada com o marcador CD23. Dessa maneira foi possível identificar as células correspondentes ao estágio I, definidas com $\mathrm{CD} 45^{+} \mathrm{CD} 19^{+} \mathrm{CD} 38^{+} \mathrm{FMC} 7^{-} \mathrm{CD} 5^{-} \mathrm{CD} 23^{-}$.

$A$ análise da população de células $C D 38^{-}$ocorreu de forma semelhante à população $\mathrm{CD}^{2} 8^{+}$. As células $\mathrm{CD} 45^{+} \mathrm{CD} 19^{+} \mathrm{CD} 38^{-}$foram analisadas com os marcadores FMC7 e CD5. A partir desta análise foram separadas as células $\mathrm{CD}^{2} 5^{+} \mathrm{CD} 19^{+} \mathrm{CD} 38^{-} \mathrm{FMC7}^{-\mathrm{CD}} 5^{-}$, $\mathrm{CD} 45^{+} \mathrm{CD} 19^{+} \mathrm{CD} 38^{-} \mathrm{FMC7} 7^{+} \mathrm{CD} 5^{+}$ e $\mathrm{CD} 45^{+} \mathrm{CD} 19^{+} \mathrm{CD} 38^{-} \mathrm{FMC7}^{+} \mathrm{CD} 5$.

Estas populações celulares foram subsequentemente analisadas com $\mathrm{O}$ marcador CD23 que permitiu a identificação das células pertencentes aos demais estágios: estágio II $\left(\mathrm{CD}^{2} 5^{+} \mathrm{CD} 19^{+} \mathrm{CD} 38^{-} \mathrm{FMC} 7^{-} \mathrm{CD} 5^{-} \mathrm{CD} 23^{-}\right)$, estágio III $\left(\mathrm{CD} 45^{+} \mathrm{CD} 19^{+} \mathrm{CD} 38^{-} \mathrm{FMC7}^{+} \mathrm{CD}^{+} \mathrm{CD} 23^{-}\right)$e estágio IV $\left(\mathrm{CD} 45^{+} \mathrm{CD} 19^{+} \mathrm{CD} 38^{-}\right.$ $\left.\mathrm{FMC}^{+} \mathrm{CD} 5^{-} \mathrm{CD} 23^{+}\right)$. Dessa forma, foram identificadas as células pertencentes aos estágios I, II, III e IV, assim como as células que permaneceram entre os estágios de diferenciação (II/III e III/IV ) (quadro 3 e figura 6).

A molécula CD23 aparece no final da maturação dos linfócitos B e um aumento da sua expressão é observado na superfície de linfócitos B maduros 
ativados. Uma vez que as células representantes dos estágios I, II e III foram negativas para CD23, estas foram consideradas células imaturas ao contrário da população celular representante do último estágio (IV) que foi positiva para CD23.

Quadro 3: Definição dos estágios de diferenciação dos linfócitos B de acordo com a expressão de diferentes marcadores de superfície celular.

\begin{tabular}{|l|l|}
\hline \multicolumn{2}{|l|}{ Estágios de diferenciação dos linfócitos B } \\
\hline Estágio I & CD45+CD19+CD38+FMC7-CD5-CD23- \\
\hline Estágio II & CD45+CD19+CD38-FMC7-CD5-CD23- \\
\hline Estágio II/III & CD45+CD19+CD38-FMC7-CD5-CD23+ \\
\hline Estágio III & CD45+CD19+CD38-FMC7+CD5+CD23- \\
\hline Estágio III/IV & CD45+CD19+CD38-FMC7+CD5+CD23+e CD45+CD19+CD38-FMC7+CD5-CD23- \\
\hline Estágio IV & CD45+CD19+CD38-FMC7+CD5-CD23+ \\
\hline
\end{tabular}

Na tabela 1 observamos uma variação na porcentagem de linfócitos B tanto entre os pacientes com CVID quanto entre os indivíduos saudáveis. Considerando os valores de referencia para porcentagens de linfócitos $B(7,7+/-2,7 \%)$ (Warnatz 2002) verificamos que a maioria dos pacientes com CVID $(87,5 \%)$ apresentou porcentagens de linfócitos $B$ dentro dos valores de referência confirmando estudos anteriores (Warnatz 2002; Kokron CM 2004).

Ao avaliar os linfócitos B de pacientes com CVID nos diferentes estágios de maturação e entre os estágios observamos que a maioria deles $(81,2 \%)$ apresentou porcentagens normais de linfócitos B maduros na circulação periférica representado pelas células presentes no último estágio de maturação (IV). Esses dados confirmam estudos anteriores que mostraram que a maioria dos pacientes com CVID apresenta números normais de linfócitos $B$ maduros na circulação periférica (Tedder 1985; Warnatz 2002).

No entanto, identificamos os pacientes (P2), (P9) e (P10) que apresentaram porcentagens diminuídas de linfócitos B maduros (estágio IV) $(21,4 \% ; 22,9 \%$ e $12,1 \%$ respectivamente) quando comparados com indivíduos saudáveis e com outros pacientes com CVID. Além de possuírem, consequentemente, maiores porcentagens de linfócitos B imaturos no estágio II (13,6\%; 10,9\%, e 19,8\% respectivamente) (tabela 1 ).

Quando observamos a porcentagem de células entre os estágios de 
maturação nos pacientes citados acima, verificamos que especialmente nos pacientes (P2) e (P10) a maior parte dos linfócitos B está presente entre os estágios III e IV (estágio III/IV, 59,7\% e 49\%, respectivamente), sugerindo que estes pacientes teriam uma dificuldade em completar o processo de maturação e formar células B maduras (Tabela 1).

A baixa porcentagem de células B nos estágios I, II e III verificadas nas amostras analisadas são resultados esperados uma vez que estas células devem estar preferencialmente nos órgãos linfóides periféricos onde devem completar seu processo de maturação (Tabela 1 e figuras 6 e 7). 
Tabela 1 - Porcentagens de linfócitos B totais e de subpopulações de linfócitos B de pacientes com CVID e de indivíduos saudáveis de acordo com a variação na expressão de diferentes marcadores de superfície celular durante as fases de maturação destas células.

\begin{tabular}{l|l|l|l|l|l|l|l|l}
\hline & LB\% & I\% & II\% & II/III\% & III\% & III/IV\% & IV\% & I todos \\
Amostras & & & & & & & & estágios \% \\
C1, 23a, (F) & 8,3 & 0 & 0 & 7,9 & 2,3 & 48 & 42 & 100 \\
C2, 25a, (M) & 3,6 & 0 & 2,6 & 0 & 0 & 32,4 & 42 & 77 \\
C3, 31a, (M) & 3,4 & 0 & 0 & 3,8 & 0 & 30,8 & 57,7 & 92,3 \\
C4, 52a, (F) & 4,7 & 0 & 0 & 9,7 & 1 & 23,5 & 59,5 & 93,7 \\
C5, 41a, (M) & 9,6 & 0 & 5,6 & 11,3 & 2,1 & 32,4 & 41,1 & 92,5 \\
C6, 42a, (M) & 11,2 & 0,2 & 3,3 & 9,8 & 1,3 & 28,7 & 43,9 & 87,2 \\
C7, 47a, (M) & 10,3 & 0,4 & 1,0 & 4,5 & 0,4 & 30,5 & 60,2 & 97 \\
C8, 34a, (F) & 16,5 & 0,2 & 2,1 & 9,3 & 2,4 & 35,2 & 40,9 & 90,1 \\
C9, 57a, (M) & 13,7 & 0,1 & 2,2 & 6,0 & 1,2 & 38,6 & 42,1 & 90,2 \\
P1, 35a, (M) & 9,8 & 0 & 2,5 & 8,3 & 1,1 & 25,1 & 58,3 & 95,3 \\
P2, 42a, (M) & 2,4 & 0 & 13,6 & 2,9 & 0 & 59,7 & 21,4 & 97,6 \\
P3, 32a, (M) & 4,7 & 0 & 0,2 & 0,4 & 2,1 & 32,1 & 59,6 & 94,4 \\
P4, 77a, (M) & 8,6 & 0 & 0,9 & 1 & 1,7 & 32,4 & 57,5 & 93,5 \\
P5, 63a, (F) & 8,2 & 0 & 1 & 2,6 & 2 & 35,1 & 49,2 & 89,9 \\
P6, 25a, (F) & 15,5 & 0 & 0,2 & 2,5 & 1,8 & 25,8 & 62,4 & 92,7 \\
P7, 23a, (F) & 9,0 & 0 & 0,6 & 3 & 4,7 & 44,1 & 42,3 & 94,7 \\
P8, 48a, (F) & 10 & 0 & 1,0 & 4,9 & 0,6 & 19,5 & 46,4 & 72,4 \\
P9, 43a, (F) & 7,6 & 0,4 & 10,9 & 21,7 & 4,9 & 26,6 & 22,9 & 87,4 \\
P10, 24a, (F) & 13,8 & 0 & 19,8 & 6,9 & 3,9 & 49 & 12,1 & 91,7 \\
P11, 53a, (M) & 11,4 & 0 & 3,2 & 7,4 & 3,6 & 37,8 & 40,1 & 92,1 \\
P12, 57a, (M) & 5,0 & 0 & 1,1 & 6,4 & 1,3 & 33,9 & 47,4 & 90,1 \\
P13, 24a, (F) & 10,8 & 0 & 1,3 & 5,3 & 3,1 & 34,4 & 51,7 & 95,8 \\
P14, 27a, (F) & 14,8 & 0 & 9,6 & 9,6 & 3,8 & 38,8 & 33,4 & 95,2 \\
P15, 38a, (F) & 18,8 & 0 & 0,4 & 3,9 & 2,4 & 23,7 & 55,2 & 85,6 \\
P16, 44a, (F) & 2,6 & 0 & 0,8 & 12,2 & 0,8 & 14,3 & 56,7 & 84,8 \\
\hline & & & & & & & & \\
\hline
\end{tabular}


C 1

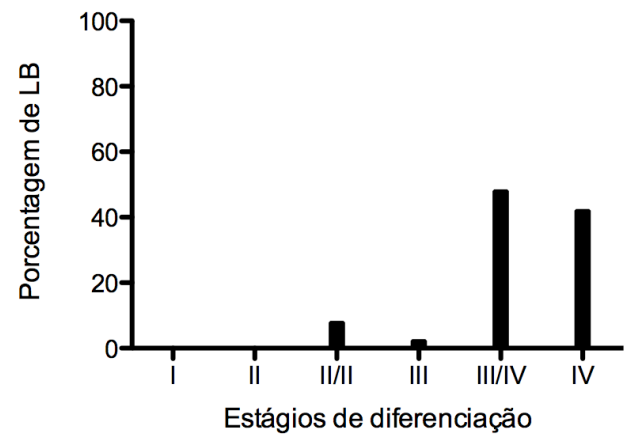

C 3

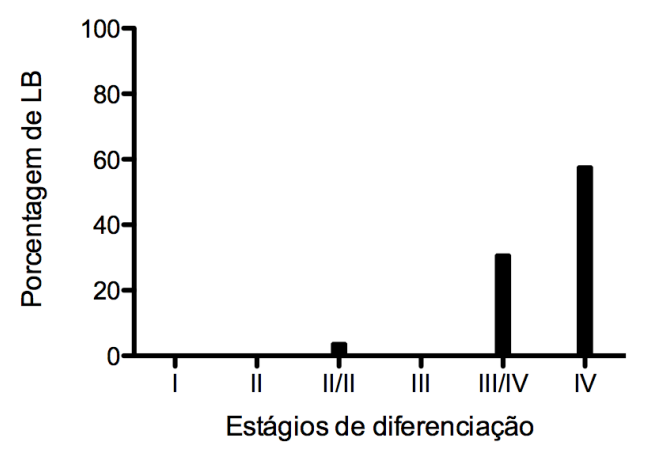

C 5

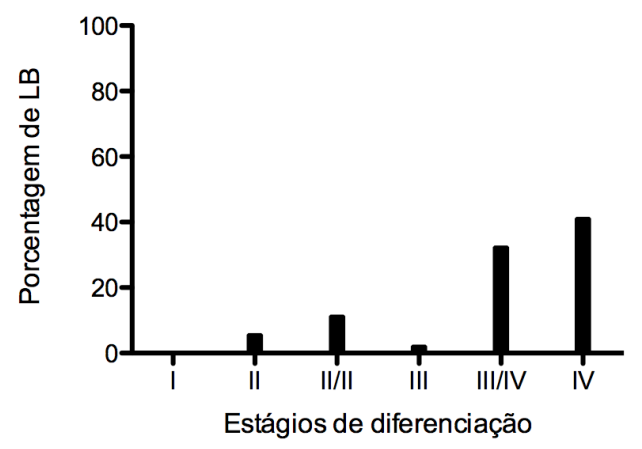

C 7

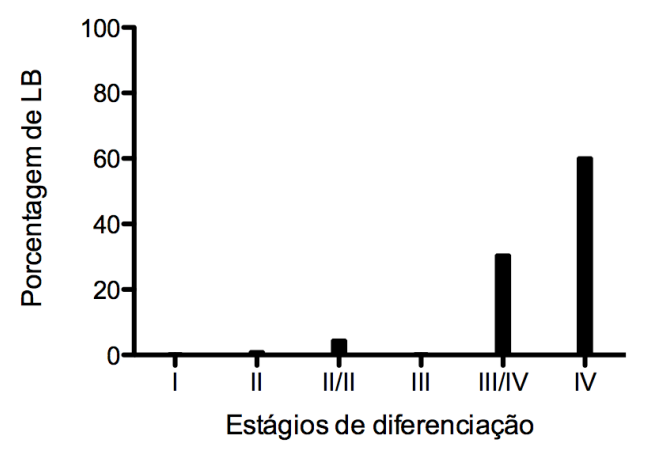

C 2

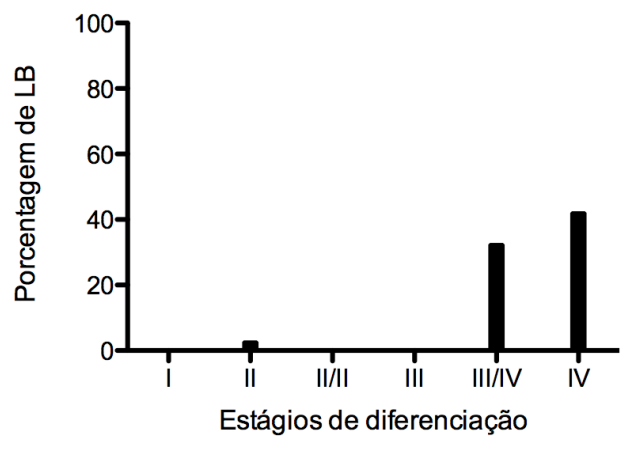

C 4

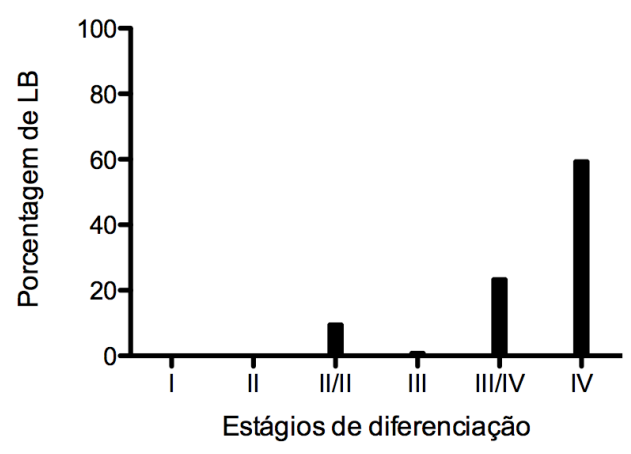

C 6

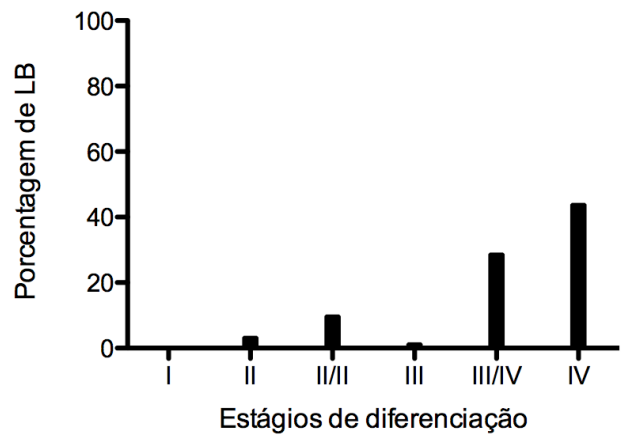

C 8

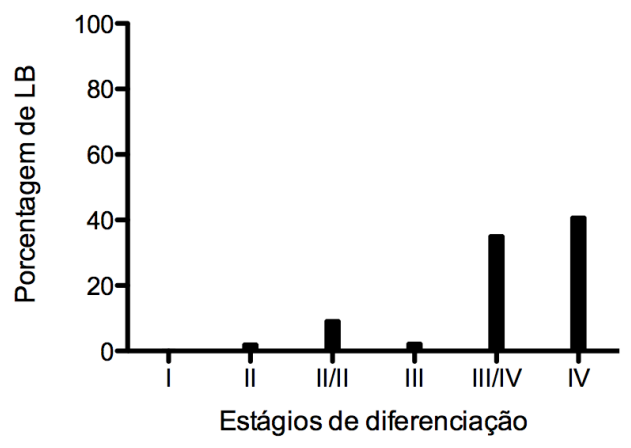


C 9

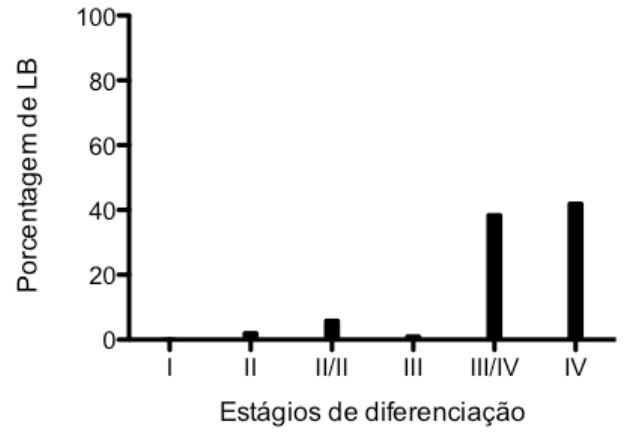

Figura 7: Porcentagem de linfócitos $B$ em diferentes estágios de diferenciação no sangue periférico de indivíduos saudáveis. A análise dos dados foi realizada de acordo com a estratégia de gating ilustrada na Figura 6 . 
P1

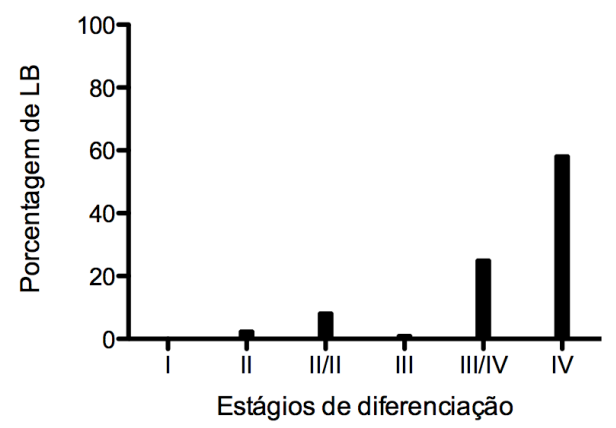

P3

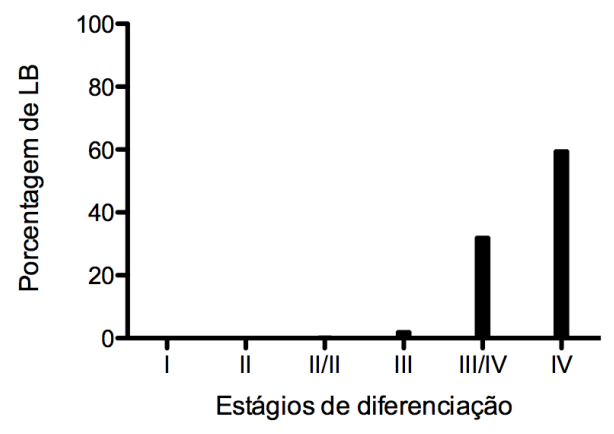

P5

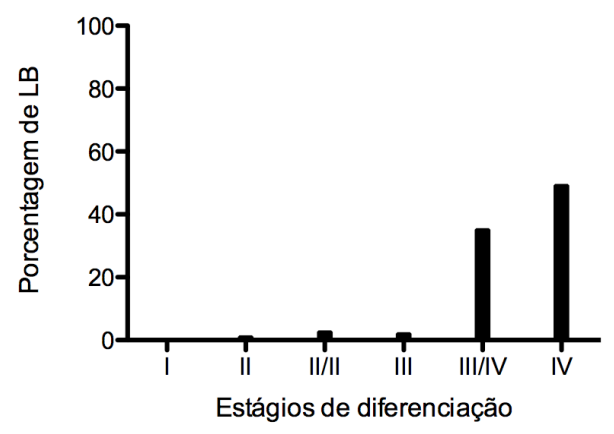

P7

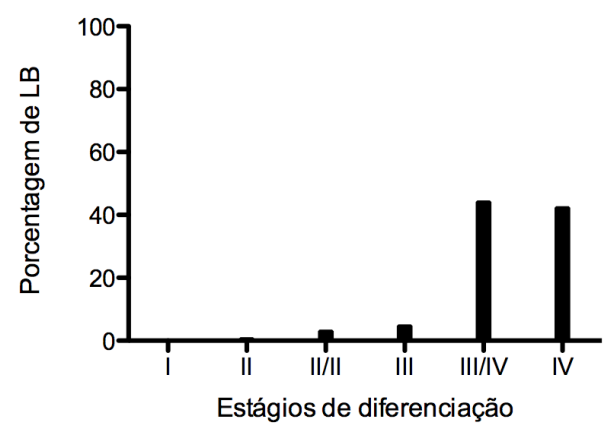

P2

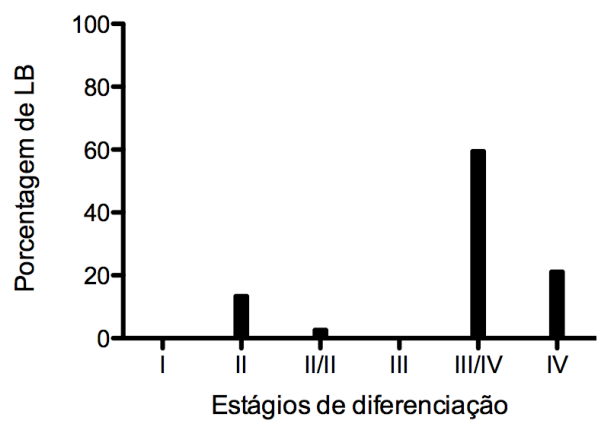

P4

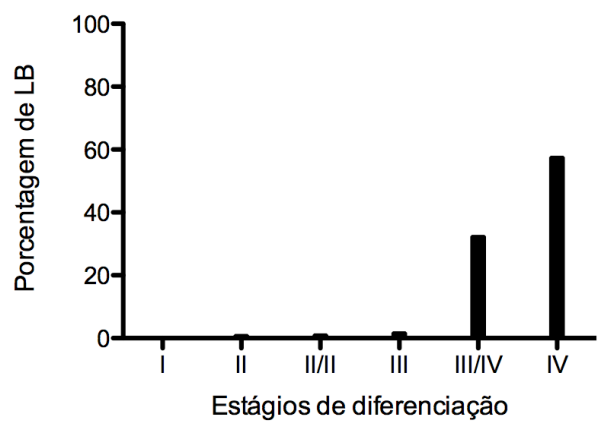

P6

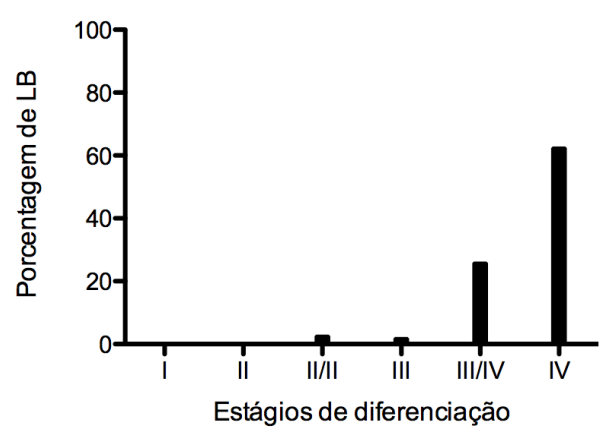

P8

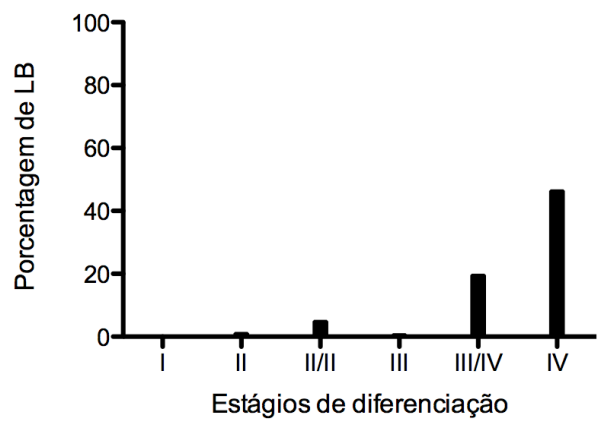


P9

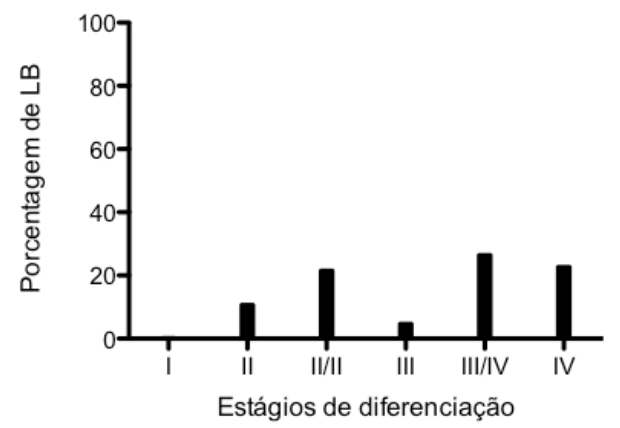

P11

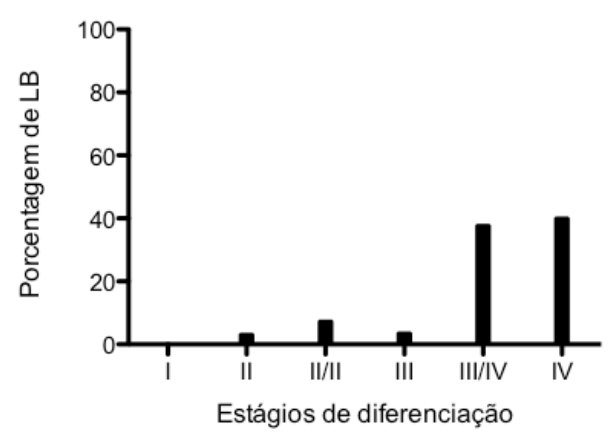

P13

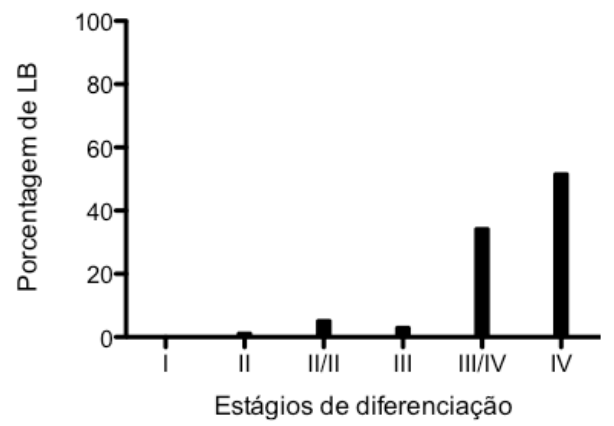

P15

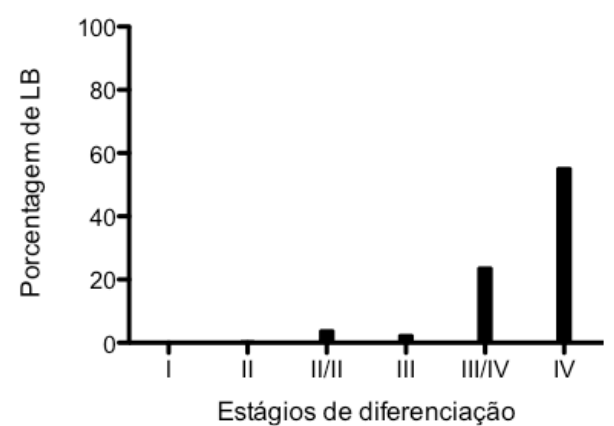

P10

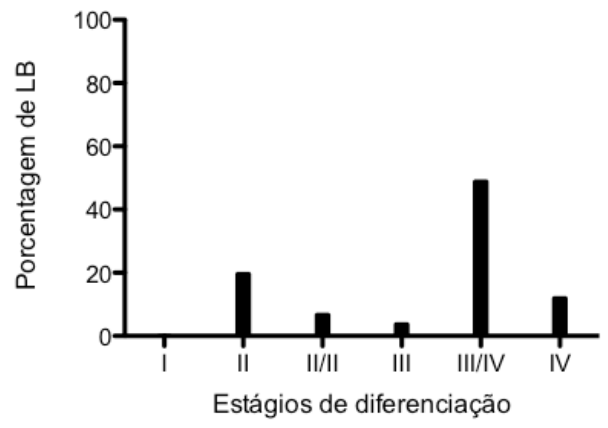

P12

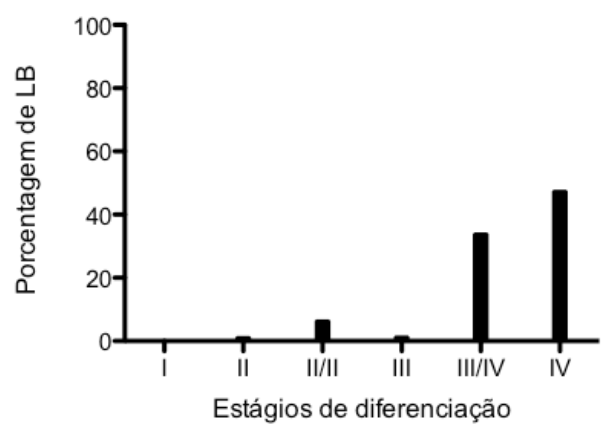

P14

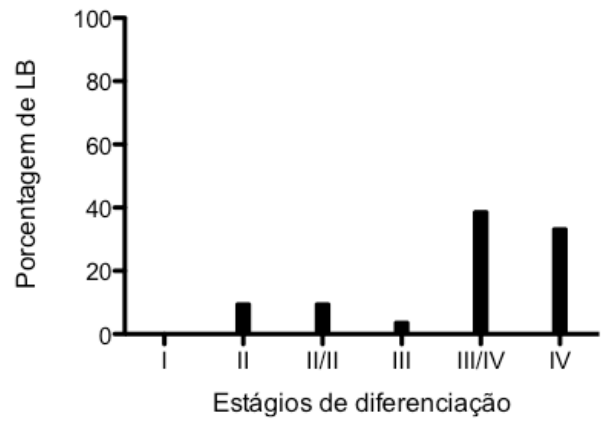

P16

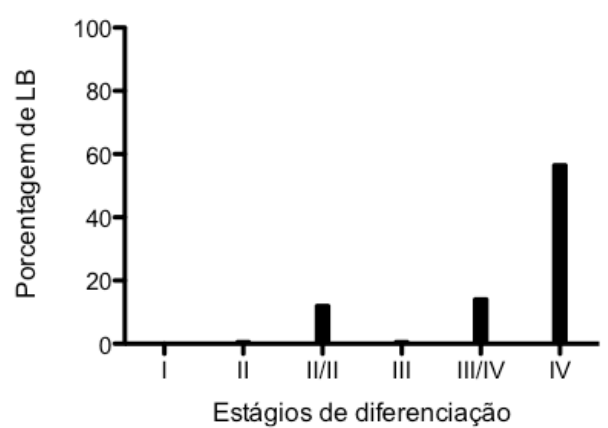

Figura 8: Porcentagem de linfócitos $B$ em diferentes estágios de diferenciação no sangue periférico de pacientes com CVID. A análise dos dados foi realizada de acordo com a estratégia de gating ilustrada na Figura 6. 

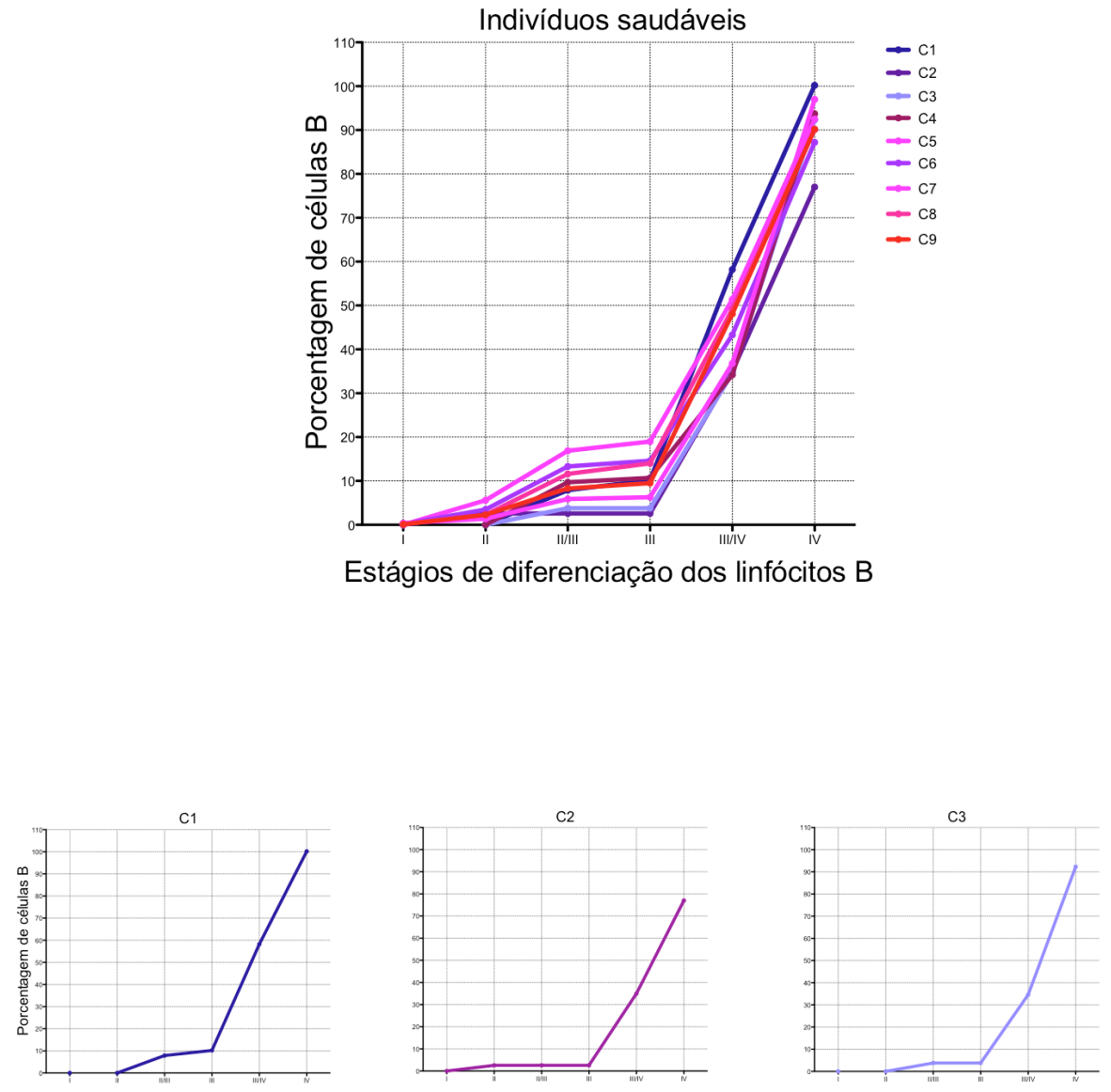

$\mathrm{C} 4$

C5
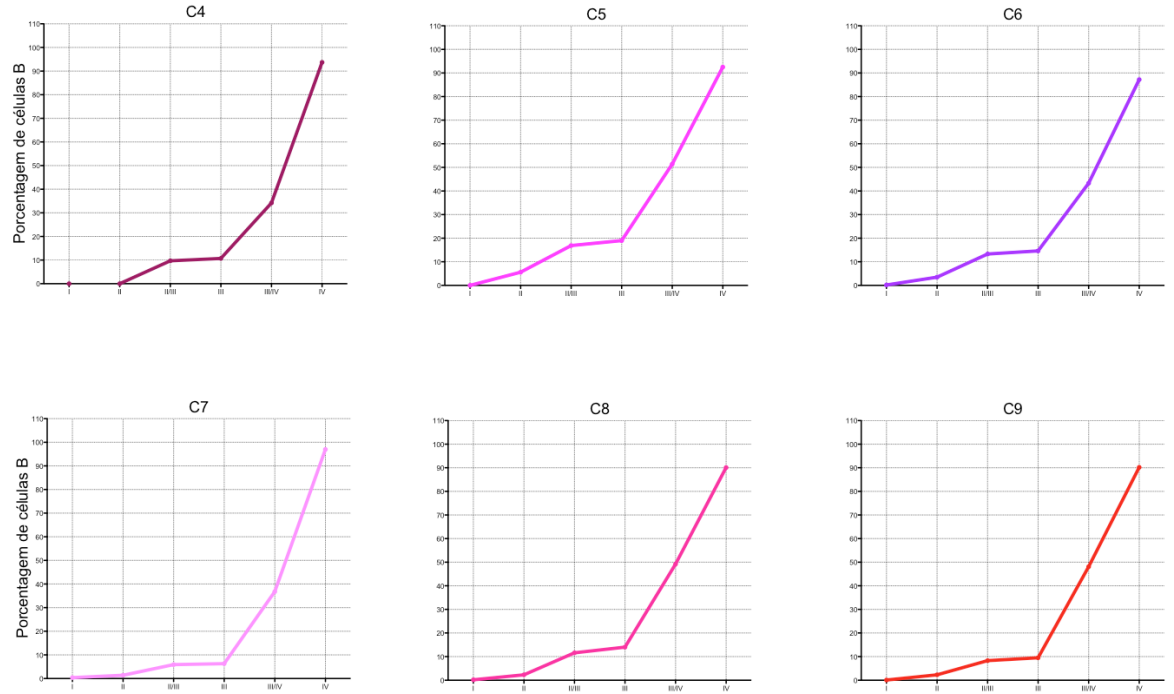

Figura 9: Gráfico cumulativo dos diferentes estágios de diferenciacão de linfócitos $B$ de sangue periférico de indivíduos saudáveis. A análise dos dados foi realizada de acordo com a estratégia de gating ilustrada na Figura 6. 


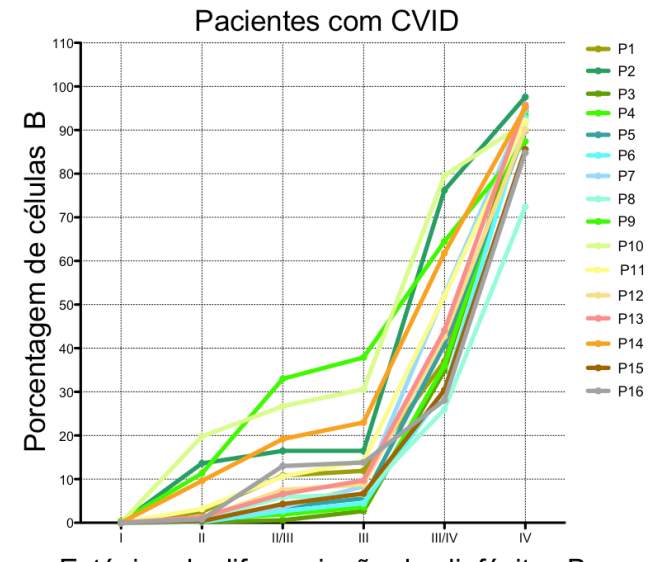

Estágios de diferenciação dos linfócitos B
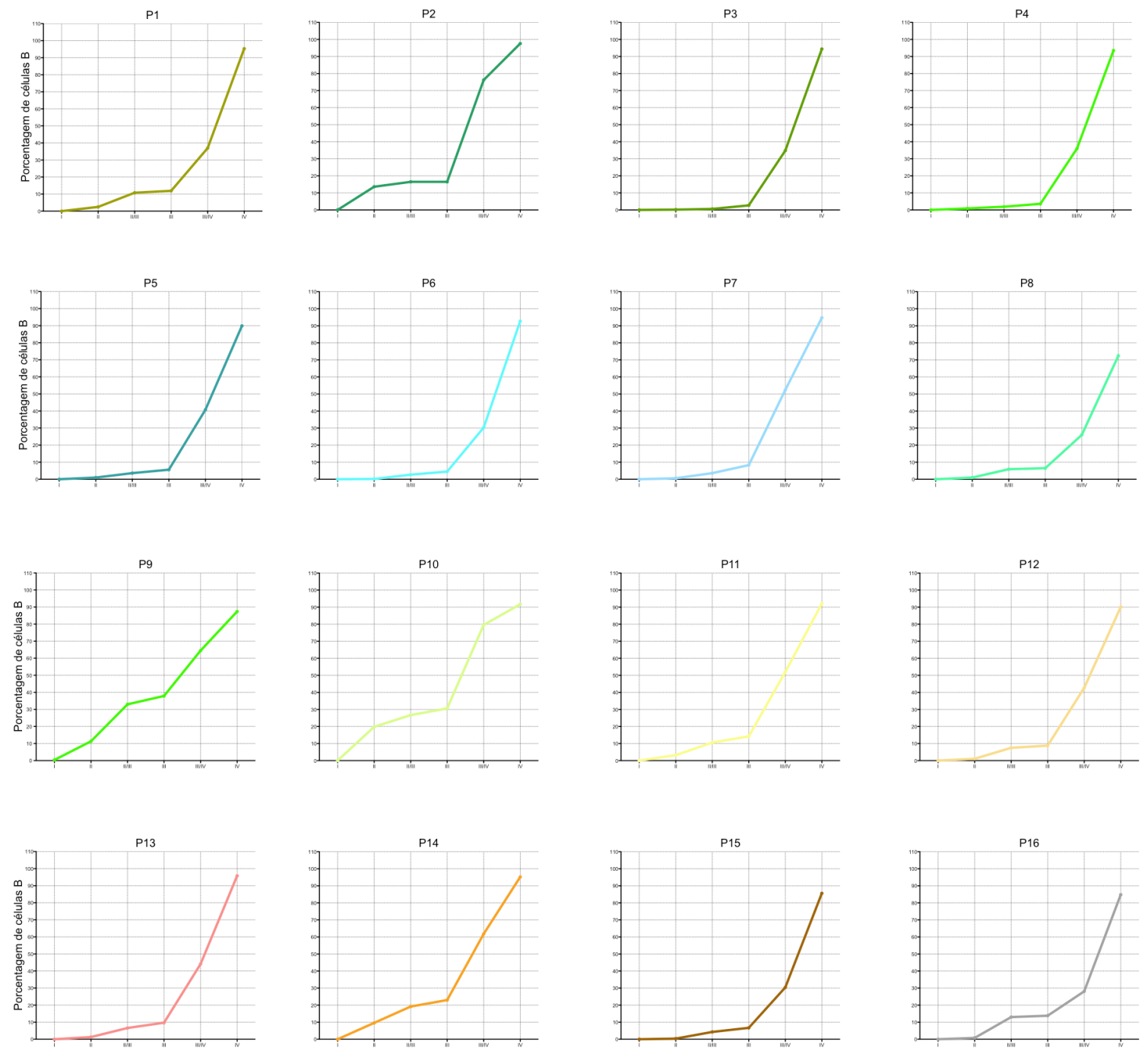

Figura 10: Gráfico cumulativo dos diferentes estágios de diferenciacão de linfócitos $B$ de sangue periférico de pacientes com CVID. A análise dos dados foi realizada de acordo com a estratégia de gating ilustrada na Figura 6. 
As figuras 9 e 10 representam uma análise cumulativa da porcentagem de linfócitos B de pacientes com CVID e de indivíduos saudáveis nos diferentes estágios de maturação destas células. Observamos que enquanto os linfócitos $B$ dos indivíduos saudáveis apresentam um perfil de maturação mais homogêneo entre si, o perfil de maturação dos linfócitos B dos pacientes com CVID mostra-se heterogêneo. Estes resultados estão de acordo com o perfil desta doença, que mostra-se bem variável entre os indivíduos afetados. Cada paciente deve ser analisado individualmente.

A caracterização fenotípica de linfócitos B de pacientes com CVID tornou-se importante nos últimos anos, principalmente por serem as células mais frequentemente acometidas e pela característica comum destes pacientes de produzirem baixas quantidades de anticorpos. Diferentemente do nosso estudo, a maioria dos trabalhos envolve a análise de linfócitos $B$ de memória, especialmente porque estes pacientes tem uma resposta imune humoral prejudicada com histórico de infecções recidivantes (Warnatz et al, 2002; Piqueras et al, 2003; Wehr et al, 2008).

No entanto, pouco se sabe a respeito de células $B$ imaturas em pacientes com CVID. Um dos primeiros estudos que relacionou a freqüência de células $B$ imaturas nestes pacientes registrou a presença destas células em um paciente com CVID dentre um total de 16 pacientes analisados. Além disso, três pacientes com CVID associada a agamaglobulinemia ligada ao sexo também apresentaram células B imaturas no sangue periférico. Estas células foram identificadas através do anticorpo monoclonal HB7, que hoje é conhecido por se ligar à molécula CD38 (Tedder et al, 1985).

Mais recentemente foi observada a presença de células $B$ definidas como $\mathrm{CD} 19^{\mathrm{hi}}, \mathrm{CD} 21^{\mathrm{lo}}, \mathrm{CD} 24^{\mathrm{lo}}, \mathrm{CD} 38^{\mathrm{lo}} \operatorname{lgM}^{\mathrm{hi}}$ consideradas células imaturas transicionais em alguns pacientes com CVID (Warnatz et al, 2002). Esses dados sugerem que a maioria dos pacientes com CVID apresenta números normais de linfócitos $B$ maduros, o que está de acordo com os nossos resultados.

Nosso laboratório identificou anteriormente uma paciente com CVID que apresentava uma desregulação da via UPR, cuja análise por microscopia confocal de linfócitos B desta paciente revelou um aumento no tamanho destas células e colocalização do retículo endoplasmático com as cadeias de lgM. Esses dados sugerem que as células desta paciente não conseguem ativar a via UPR 
corretamente resultando num acúmulo de proteínas desdobradas no interior do retículo endoplasmático (Kuribayashi et al, 2008).

Baseado neste achado, nos propusemos a investigar a via UPR em alguns destes pacientes para verificar se poderia haver uma correlação entre imaturidade de células B no sangue periférico de pacientes com CVID e desregulacão da via UPR.

Foram incluídas nesta análise amostras de pacientes com CVID que apresentaram porcentagens normais de linfócitos B maduros (P7, P13 e P15), amostras de pacientes com porcentagens menores de linfócitos $B$ maduros e com maiores porcentagens de linfócitos B imaturos (P2 e P9), além de amostras de indivíduos saudáveis (C5 e C6).

A paciente (P6) identificada no trabalho anterior também fez parte de nossa análise por citometria de fluxo e verificamos que ela possui porcentagens normais de linfócitos B totais e de linfócitos B maduros. Esses resultados sugerem que a hipogamaglobulinemia desta paciente não é conseqüência de linfócitos B imaturos.

\subsection{Avaliação da via UPR em linfócitos B de pacientes com CVID}

Considerando que a diferenciação de linfócitos B em plasmócitos induz a ativação da via UPR devido ao aumento na produção imunoglobulinas recémsintetizadas no retículo endoplasmático, utilizamos pacientes com CVID como modelo experimental para avaliação da disfunção da via UPR em humanos .

O LPS foi o estímulo escolhido para essa avaliação, uma vez que o tratamento com células $B$ de baço de camundongo com LPS in vitro é um sistema experimental bem estabelecido para estudo de diferenciação de linfócitos $B$ em plasmócitos. Depois de quatro dias em cultivo aproximadamente $30 \%$ das células alcançam o fenótipo de plasmócitos, avaliado pela expressão da molécula de superfície celular Syndecam-1 e pela secreção de imunoglobulinas (Lafrenz et al, 1982; Schliephake et al, 1996).

Estudos sobre a expressão de receptores tipo Toll (TLR- Toll like receptors) em linfócitos $B$ humanos tem revelado uma maior expressão de TLR1, TLR2, TLR9 e TLR10 nestas células, enquanto que a expressão de TLR4 é baixa ou ausente 
(Hornung et al, 2002; Bourke et al, 2003; Dasari et al, 2005). E diferentemente do que é observado em camundongos, o TLR4 em linfócitos B humanos não responde ao LPS (Muzio et al, 2000; Bourke et al, 2003).

Os linfócitos $B$ de pacientes com CVID e de indivíduos saudáveis foram obtidos pelo método de separação RosetteSep Human B Cell Enrichment Cocktail (Stem Cell Technologies) e a pureza das amostras foi verificada no citômetro FACS Canto Il após marcação das células com CD19-PE e CD3-FITC (figura 9).

Uma vez que o marcador CD19 é específico de linfócitos B e o CD3 está presente nos linfócitos $T$ foi possível quantificar os linfócitos $B$. A porcentagem obtida de $80,7 \%$ de linfócitos $B$ está dentro das especificações do kit.

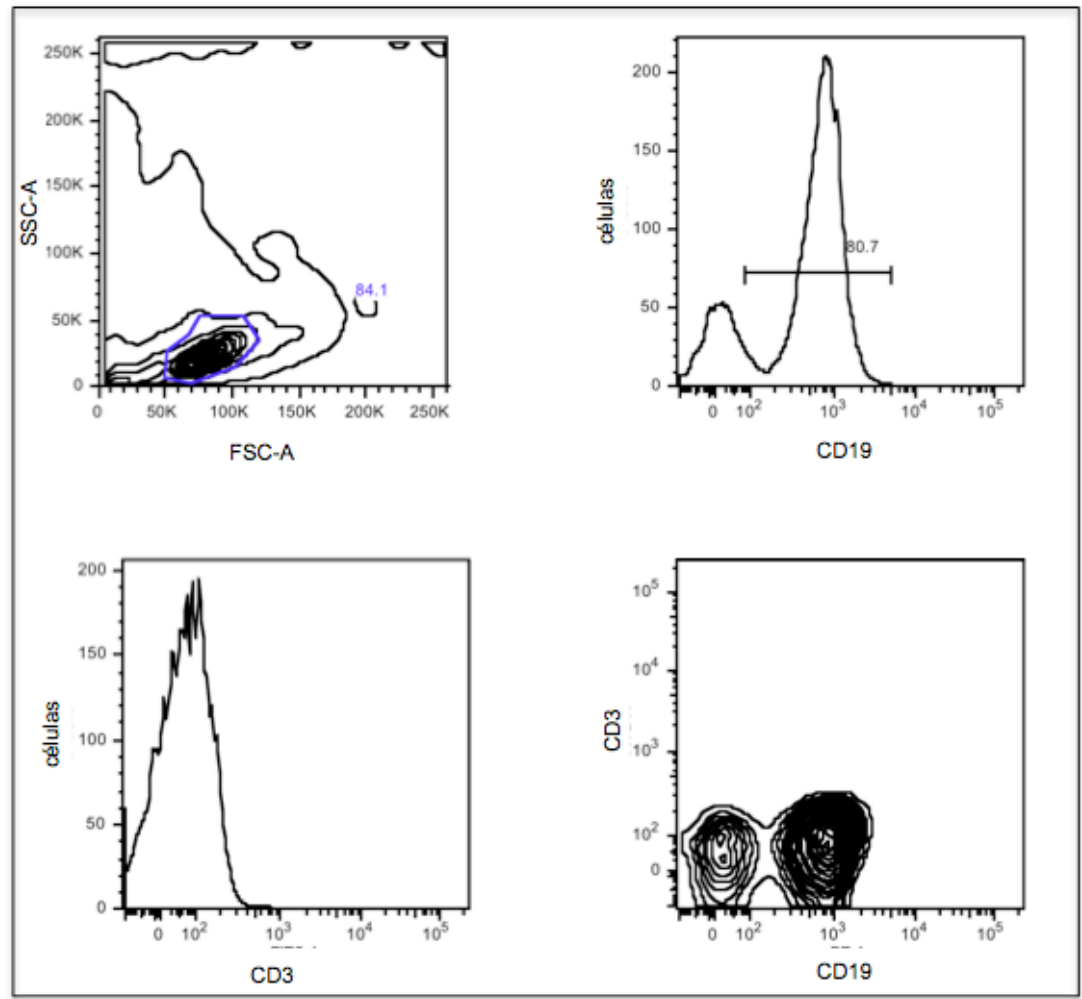

Figura 11: Determinação de pureza das células $B$ de sangue periférico obtidas após separação com o kit RosetteSep Human B Cell Enrichment Cocktail (Stem Cell Technologies). Quadrante superior esquerdo mostra o gate em linfócitos de acordo com os parâmetros de tamanho (FSC) versus granulosidade (SSC). No quadrante superior direito um histograma mostra que mais de $80 \%$ das células representam linfócitos $\mathrm{B}$ por serem $\mathrm{CD} 19^{+}$. No quadrante inferior esquerdo usando o marcador CD3 específico para linfócitos $T$ exclui a presença destas células na amostra. O quadrante inferior direito mostra que a maior parte das células são representadas por células $\mathrm{CD}^{-} \mathrm{CD} 19^{+}$. 
Em seguida, essa população celular enriquecida em linfócitos B foi mantida em cultura por 12 ou 24 horas na ausência ou presença de LPS (10 $\mu \mathrm{g} / \mathrm{ml})$. Após o tratamento, verificamos em tempo real a expressão relativa de $x b p-1 s$ (Figura 12) e bip (Figura 13).

Nesta análise foram avaliados pacientes com porcentagens normais de linfócitos B maduros (P7), (P13) e (P15) e pacientes com porcentagens diminuídas de linfócitos $B$ maduros e maiores porcentagens de linfócitos $B$ imaturos (P2) e (P9), além de indivíduos saudáveis (C5) e (C6). 
P2

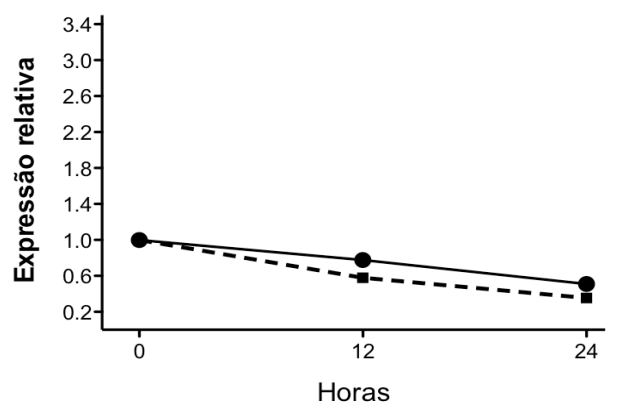

P9

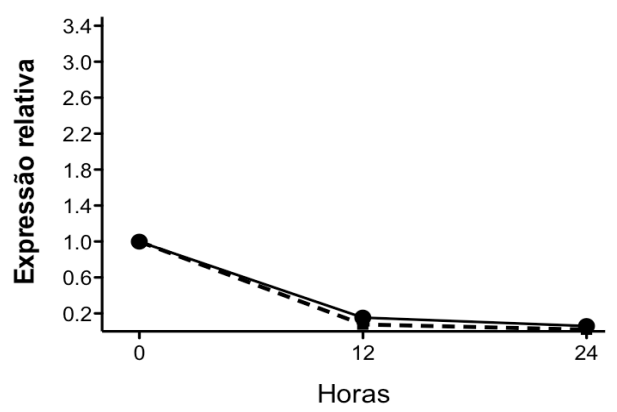

P15

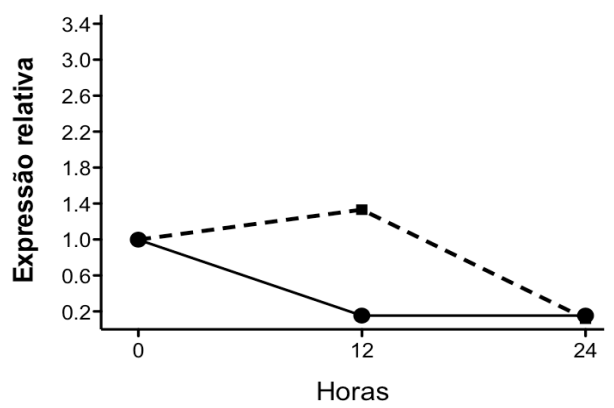

C5

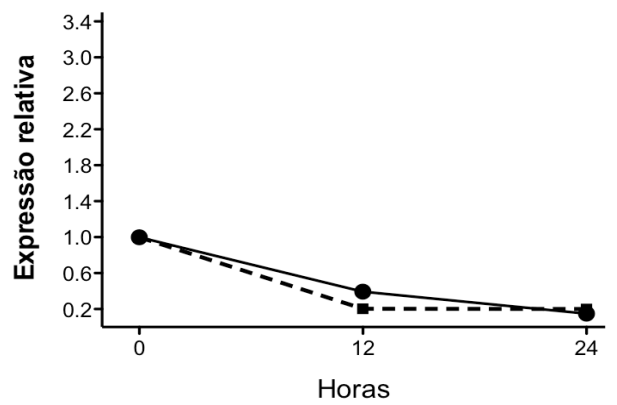

P7

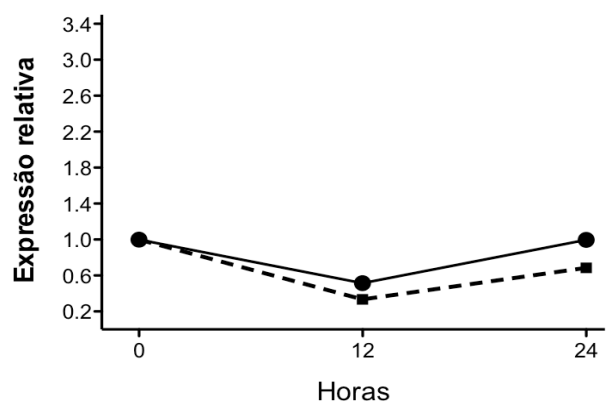

P13

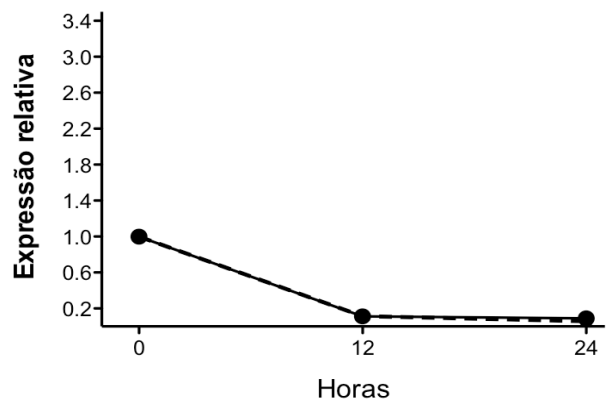

s/LPS

$\rightarrow$ c/LPS

C6

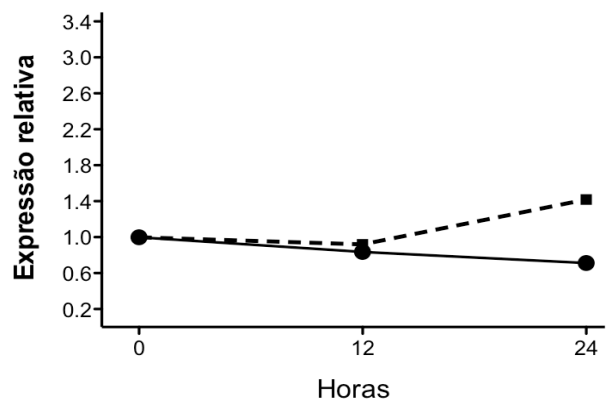

Figura 12: Expressão relativa de $x b p-1 s$ de linfócitos $B$ de pacientes com CVID e de indivíduos saudáveis no estado basal (células ex-vivo) na presença e na ausência de $10 \mu \mathrm{g} / \mathrm{ml}$ de LPS por 12 ou 24 horas. 
P2

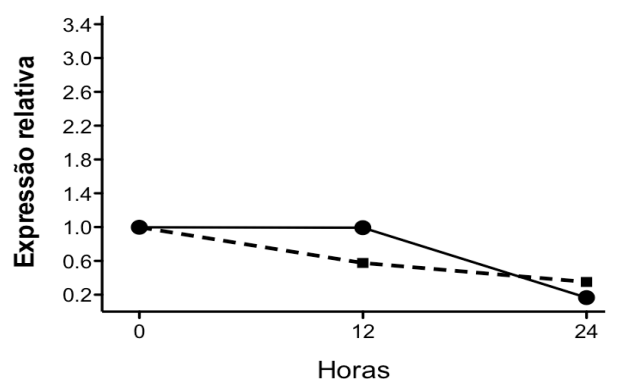

P9

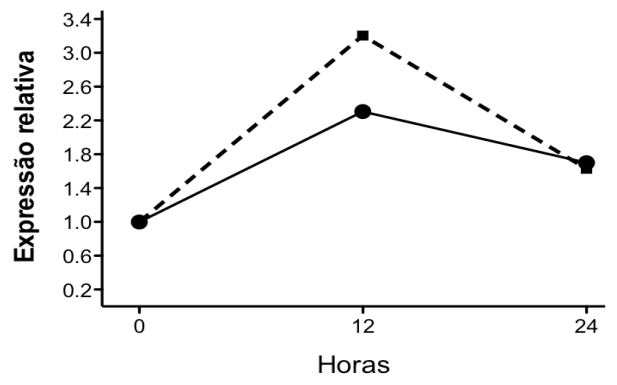

P15

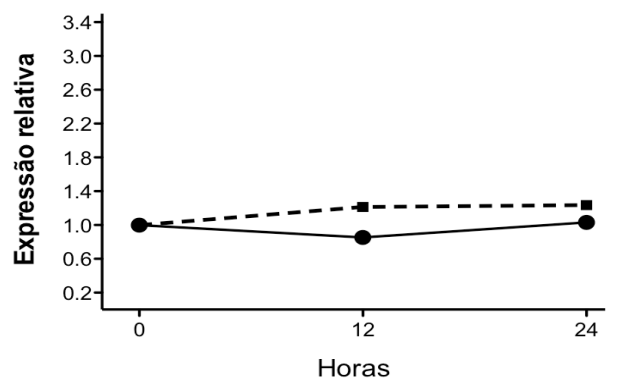

C5

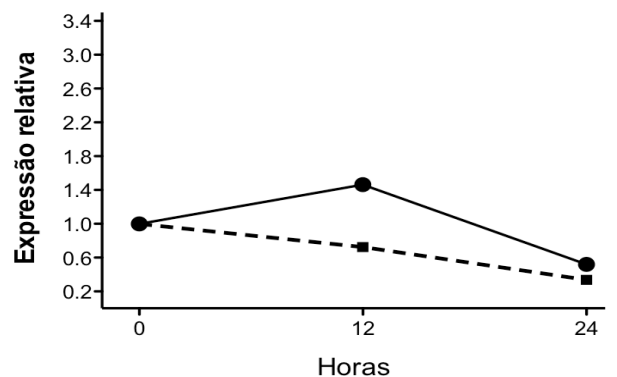

P7

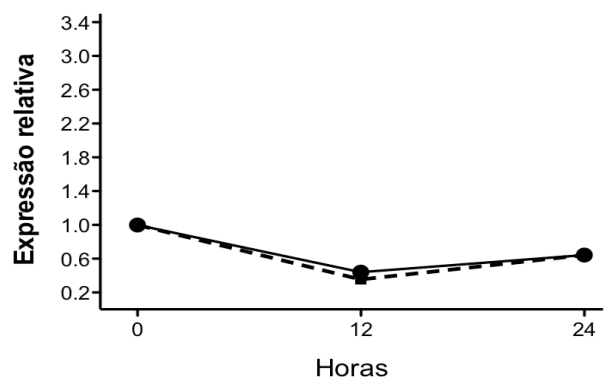

P13

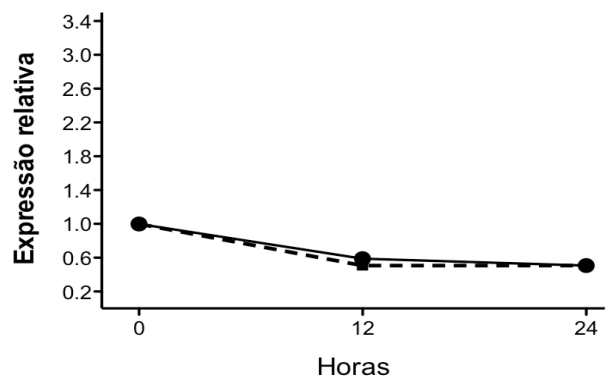

- s/LPS C/LPS

C6

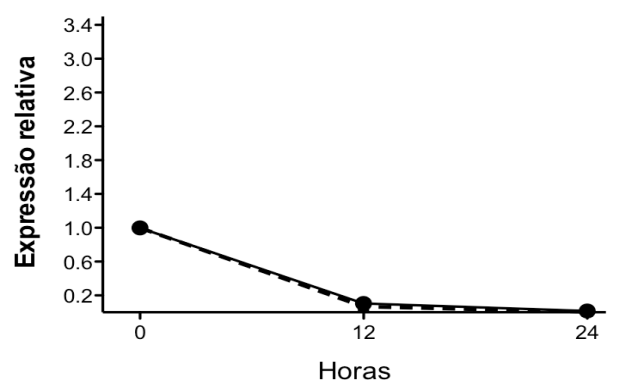

Figura 13: Expressão relativa de bip de linfócitos $B$ de pacientes com CVID e de indivíduos saudáveis no estado basal (células ex-vivo) na presença e na ausência de $10 \mu \mathrm{g} / \mathrm{ml}$ de LPS por 12 ou 24 horas. 
Considerando que a expressão relativa igual a 1 refere-se a expressão basal do genes em análise, observamos na figura 12 que a maioria dos pacientes com CVID e dos indivíduos saudáveis não apresentaram aumento na expressão de $x b p$ $1 s$ após estímulo por LPS.

No entanto, observamos que os linfócitos $B$ da paciente (P15) apresentaram um aumento na expressão de $x b p-1 s$ após 12 horas de LPS. Esse resultado sugere a presença de ativação da via UPR nesta paciente uma vez que o splicing do RNAm de $x b p-1 s$ leva a geração da forma ativa do fator de transcrição XBP-1s que tem papel importante na via UPR induzindo a transcrição de chaperonas e melhorando a capacidade de dobramento de proteínas no retículo endoplasmático.

Quando avaliamos a expressão de bip nesta paciente, verificamos um aumento na expressão 12 horas após LPS, correlacionando com um aumento respectivo da expressão de $x b p-1 s$ citado anteriormente. Este resultado está em conformidade com o mecanismo de ativação da via UPR e reforça nossa suposição de ativação da via UPR nesta paciente.

A paciente (P9) por sua vez, apresentou um aumento na expressão de bip após 12 horas de LPS, mas não observamos um aumento respectivo de expressão de $x b p-1 s$. Interessantemente, esta paciente mostrava um aumento na expressão de bip mesmo na ausência do estímulo sugerindo que os linfócitos $B$ desta paciente estivessem em estresse mesmo antes da ativação in vitro por LPS.

Alem disso, a análise do perfil de maturação de linfócitos $B$ desta paciente revelou um aumento nas porcentagens de linfócitos $B$ imaturos com $21 \%$ de células no estágio (II/III), 26,6\% no estágio (III/IV) além da paciente possuir uma menor porcentagem $(22,9 \%)$ de linfócitos B maduros. Esses dados sugerem um defeito no processo de maturação destas células. 'E possível que um provável defeito neste programa interfira na qualidade das células B que são liberadas para circulação periférica desta paciente. O fato destes linfócitos estarem ativados mesmo na ausência do LPS pode indicar um dano na função destes linfócitos. Infelizmente não foi possível avaliar a função destas células. A análise do perfil de ativação e proliferação destes linfócitos poderia contribuir para uma melhor compreensão dos nossos dados obtidos até o momento.

De um modo geral, os nossos resultados da avaliação da ativação do braço IRE-XBP da via UPR medidos pela transcrição dos RNAm de bip e xbp-1s em pacientes com CVID a princípio, não mostraram uma correlação entre a presença de 
maiores quantidades células imaturas no sangue periférico e ativação da via UPR. Os pacientes (P2) e (P9) que apresentaram uma porcentagem maior de linfócitos $B$ imaturos pela análise por citometria de fluxo apresentaram um perfil de ativação da via UPR diferente entre si.

No entanto, apesar de termos analisado a via UPR em apenas dois pacientes com perfil imaturo, vale ressaltar que a CVID é uma doença heterogênea, que pode apresentar defeitos em vários compartimentos do sistema imune e é possível que mesmo em uma maior amostragem cada paciente possa apresentar um padrão diferente de ativação da via UPR.

Além disso, diferentemente de outros estressores do retículo endoplasmático, tais como: tapsigardina, DTT e tunicamicina que induzem de maneira mais robusta a ativação da via UPR, os nossos resultados com LPS em linfócitos B humanos in vitro mostram um perfil de ativação diferente. Infelizmente, os estudos que avaliam a indução da ativação da via UPR por LPS tem sido realizados em modelos animais, de modo que não temos dados comparativos em humanos.

Considerando que a dose de LPS utilizada nos nossos experimentos possa ser a causa de uma ativação da via UPR mais discreta, nos propusemos a avaliar diferentes concentrações deste agente para verificar sua capacidade de induzir genes alvos da via UPR, entre eles a bip e ire1.

\subsection{Cinética de ação do LPS em células B imortalizadas com vírus Epstein Barr}

Foram utilizadas células $B$ de indivíduos saudáveis (Controle $L$ e Controle $P$ ) imortalizadas com vírus Epstein Barr, devido a facilidade de obtenção destas células em cultura.

Considerando que a concentração de $10 \mu \mathrm{g} / \mathrm{ml}$ de LPS representa uma elevada quantidade de LPS, partimos desta concentração e fizemos diluições seriadas $(10 \mu \mathrm{g} / \mathrm{ml}, 100 \mathrm{ng} / \mathrm{ml}, 1 \mathrm{ng} / \mathrm{ml}, 10 \mathrm{pg} / \mathrm{ml}$ e $100 \mathrm{fg} / \mathrm{ml}$ ) com o intuito de verificar qual a concentração de LPS capaz de induzir a via UPR e a qual o máximo de estímulo que a célula B saudável consegue suportar. Além disso, verificar se o padrão resposta em relação ao LPS é semelhante ou diferente entre os indivíduos.

Foi avaliada a expressão relativa de ire1 e bip 12 horas e 36 horas após 
estímulo in vitro com LPS. As figuras 14 e 15 representam os resultados da expressão relativa de ire1 e bip de acordo com a concentração de LPS utilizada tanto após 12 horas quanto 36 horas de estímulo de LPS. 


\section{Controle P}

$10 u g / m l$

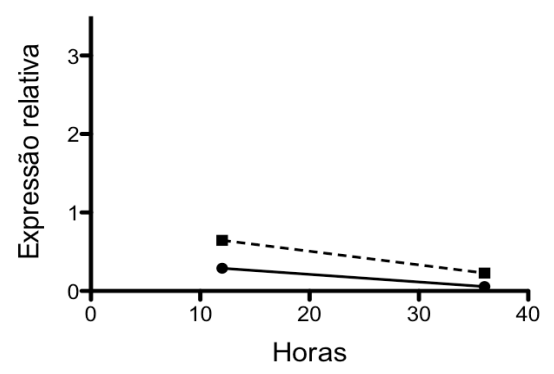

$1 \mathrm{ng} / \mathrm{ml}$

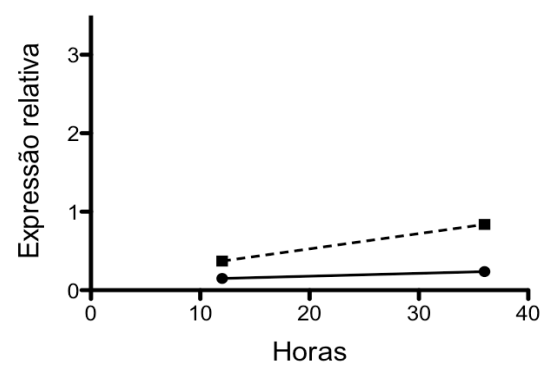

$100 \mathrm{fg} / \mathrm{ml}$

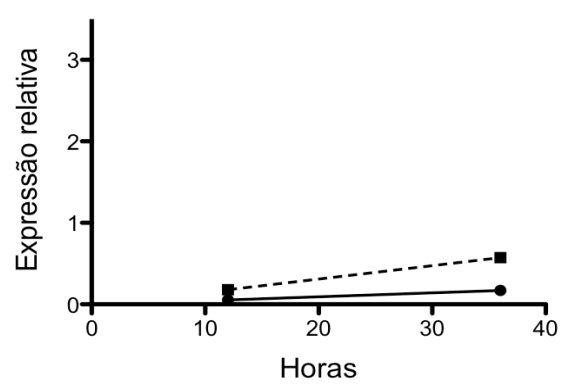

$100 \mathrm{ng} / \mathrm{ml}$

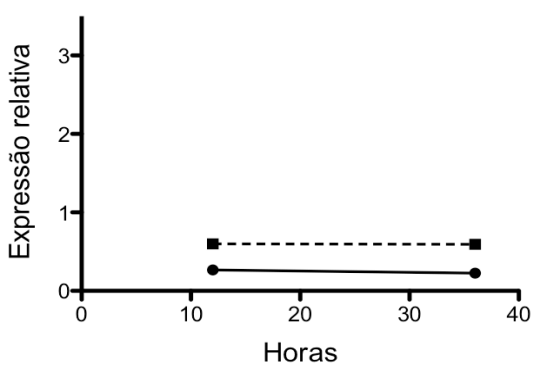

$10 \mathrm{pg} / \mathrm{ml}$

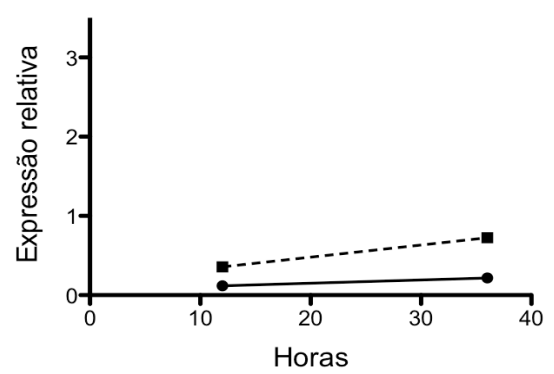

Figura 14: Expressão relativa de ire1 e bip em células $B$ de indivíduo saudável (Controle $P$ ) imortalizada com vírus Epstein Barr após tratamento com diferentes concentrações de LPS por 12 ou 36 horas. 


\section{Controle L}

$10 \mathrm{ug} / \mathrm{ml}$

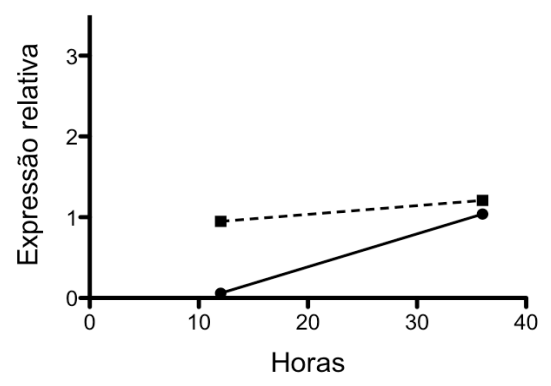

$1 \mathrm{ng} / \mathrm{ml}$

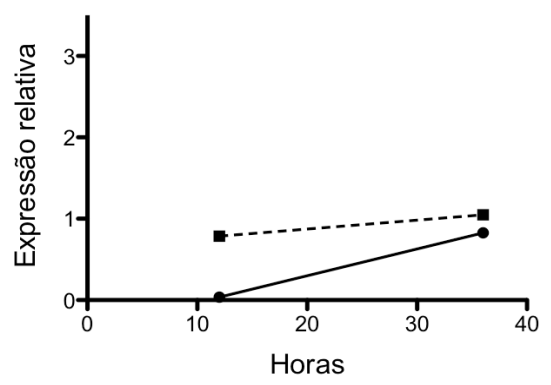

$100 \mathrm{fg} / \mathrm{ml}$

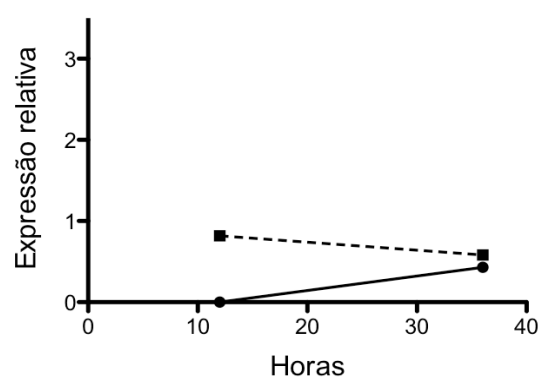

$100 \mathrm{ng} / \mathrm{ml}$

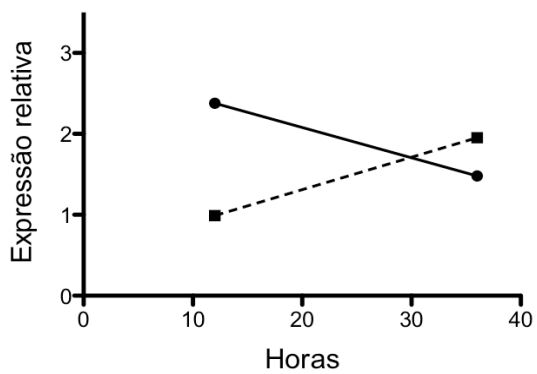

$10 \mathrm{pg} / \mathrm{ml}$

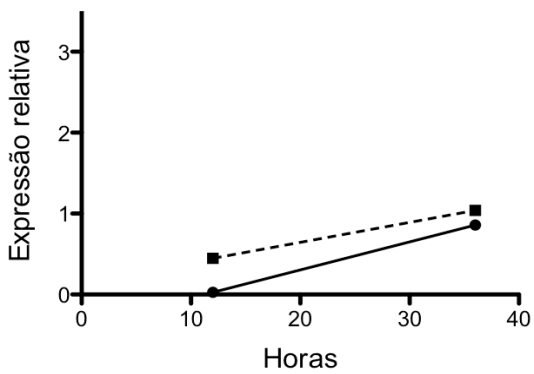

- - - ire 1

$\rightarrow$ bip

Figura 15: Expressão relativa de ire1 e bip em células B de indivíduo saudável (Controle L) imortalizada com vírus Epstein Barr após tratamento com diferentes concentrações de LPS por 12 ou 36 horas. 
Observamos no controle $\mathrm{P}$ que as diferentes concentrações de LPS utilizadas não foram suficientes para induzir um aumento na expressão de genes alvo da via UPR (ire1 e bip), uma vez que os valores obtidos foram inferiores a expressão basal considerada igual a 1(Figura 14).

$O$ controle $L$ quando estimulado com concentrações menores de LPS (1 $\mathrm{ng} / \mathrm{ml}, 10 \mathrm{pg} / \mathrm{ml}$ e $100 \mathrm{fg} / \mathrm{ml}$ ) não apresentou aumento na expressão dos RNAm de (ire1 e bip) nos tempos 12 e 36 horas (Figura 15). Mas, diferentemente do controle $P$, o controle L na concentração de LPS de $100 \mathrm{ng} / \mathrm{ml}$ apresentou um aumento na expressão tanto de ire1 quanto de bip (Figura 15).

Além disso, a análise dose-resposta da expressão bip do controle $\mathrm{L}$ na concentração de $100 \mathrm{ng} / \mathrm{ml}$ de LPS mostrou um padrão de ativação que está em conformidade com o perfil de ativação da via UPR, com um aumento da expressão desse gene 12 horas após LPS seguido de um declínio no tempo 36 horas, sugerindo que o retículo endoplasmático esteja em fase de restabelecimento de sua homeostasia.

Inicialmente estes dados mostram que o padrão de ativação da via UPR em resposta ao LPS é diferente entre os indivíduos. Além disso, sugere que concentrações abaixo de $100 \mathrm{ng} / \mathrm{ml}$ sejam insuficientes para agir como estressor do retículo endoplasmático em linfócitos $B$ imortalizados humanos in vitro.

Em relação a concentração de $10 \mu \mathrm{g} / \mathrm{ml}$, que foi até o momento a concentração de escolha do LPS nos nossos experimentos, os dados da cinética sugerem que essa concentração não seria a melhor escolha. Não há relatos de avaliação da ativação da via UPR em linfócitos $B$ humanos in vitro apos estímulo com LPS.

No entanto, em estudos com modelos animais observamos uma variação na concentração de LPS utilizada (10 $\mu \mathrm{g} / \mathrm{ml}$ a $50 \mu \mathrm{g} / \mathrm{ml})$, que pode ser decorrente dos tipos celulares avaliados. Esses resultados sugerem a necessidade de conhecer previamente a cinética de ação do LPS a ser utilizado num modelo experimental.

De um modo geral não houve aumento na expressão de bip e ire1 na concentração de $10 \mu \mathrm{g} / \mathrm{ml}$ e apenas no controle L, após 36 horas de estímulo, verificamos um discreto aumento. Não sabemos se isso seria resultado de uma concentração muito elevada que poderia induzir a morte celular pois infelizmente, não verificamos o número de células vivas e mortas após o período de incubação 
com LPS.

Alguns grupos tem utilizado o LPS para avaliação da via UPR após diferenciação em plasmócitos em modelos animais e tem observado ativação da via UPR. Em um deles, foi observado que células $B$ de baço de camundongos quando estimuladas com $10 \mu \mathrm{g} / \mathrm{ml}$ de LPS (Salmonela typhi) apresentaram um aumento na expressão de bip, atingindo um pico máximo de três vezes o valor basal em 72 horas após estímulo com LPS. Neste mesmo estudo, a análise da expressão de $x b p-1 s$ revelou um aumento dessa expressão em 24 horas e 48 hor etas na presença de LPS e que culmina com um máximo em 72 horas com LPS, representado por um aumento de 10 vezes a expressão basal (Skalet et al, 2005).

Por outro lado, quando células B de baço de camundongo foram tratadas com $50 \mu \mathrm{g} / \mathrm{ml}$ de LPS verificou-se que o aumento na expressão de bip ocorreu depois de 36 horas de estímulo (Sheng e Hendershot, 2002).

Um outro estudo utilizou células B de linhagem de linfoma $1.29^{+}$murino e quando tratadas com $20 \mu \mathrm{g} / \mathrm{ml}$ de LPS, verificou-se um aumento na expressão de $x b p-1 s$ depois de 48 horas, enquanto que essas mesmas células quando tratadas com tunicamicina apresentaram um aumento após 6 horas de estímulo (van Anken et al, 2003). Neste caso, a diferença no tempo de início da ativação entre os estressores utilizados (LPS e tunicamicina) revela que assim como outros estressores farmacológicos, a tunicamicina é um potente ativador da via UPR.

Diferentemente, nossos resultados mostram que nos indivíduos onde houve um aumento na expressão de bip, isso ocorreu após 12 horas de tratamento com LPS seguido por um declínio no tempo 24 horas.

A variação no perfil de ativação da via UPR entre os estudos com modelos animais sugere que isso pode ser devido a diferenças técnicas tais como: concentração de LPS, tipo de LPS (proveniente de qual bactéria), tipo celular em estudo. De qualquer forma, apesar do perfil de ativação ser diferente entre os estudos com modelos animais, eles mostram que o LPS é um agente capaz de induzir ativação da via UPR.

Nossos resultados no entanto, sugerem que em linfócitos $B$ humanos in vitro o LPS não é capaz de ativar a via UPR de forma robusta, uma vez que apenas o paciente (P9) apresentou um aumento significativo na expressão de bip. 


\section{$\underline{5 \text { CONCLUSÃO }}$}

A análise do perfil de maturação de linfócitos $B$ de pacientes com CVID revelou a presença de maiores porcentagens de células $B$ imaturas em alguns pacientes que pode contribuir para o quadro de hipogamaglobulinemia característico desta doença.

Interessantemente em um destes pacientes com perfil imaturo de células B observamos a ativação da via UPR na ausência de um agente estressor. Ė possível que um defeito no programa de maturação dos linfócitos deste paciente interfira na qualidade de células $B$ que são formadas.

Além disso, concluímos que, diferentemente do que é observado em camundongos, o LPS quando utilizado em linfócitos $B$ humanos in vitro não induz estresse do retículo endoplasmático de forma robusta. 


\section{REFERÊNCIAS $^{\star}$}

Allman D, Srivastava B, Lindsley RC. Alternative routs to maturity: branch points and pathways for generating follicular and marginal zone B cells. Immunol Rev. 2004; 197:147-60.

Allman D, Lindsley RC, DeMuth W, Rudd K, Shinton SA, Hardy, RR. Resolution of the three nonproliferative immature splenic $B$ cell subsets reveals multiple selection points during peripheral B cell maturation. J Immunol. 2001;167(12):6834-40.

Agematsu K, Nagumo H, Yang FC, Nakagawa T, Fukushima K, Ito S, Sugita K, Mori T, Kobata T, Morimoto C, Komiyama A. B cell subpopulations separated by CD27 and crucial collaboration of $\mathrm{CD} 27+\mathrm{B}$ cells and helper $\mathrm{T}$ cells in immunoglobulin production. Eur J Immunol. 1997; 27(8):2073-9.

Ansel KM, Harris RB, Cyster JG. CXCL 13 is required for B1 cell homing, natural antibody production and body cavity immunity. Immunity. 2002;16(1):67-76.

Aspalter RM, Sewell WA, Dolman K, Farrant J, Webster AO. Deficiency in circulating natural killer (NK) cell subsets in common variable immunodeficiency and X-linked agammaglobulinaemia. Clin Exp Immunol. 2000;121(3):506-14.

Banchereau J, Rousset F. Human B lymphocytes: phenotype, proliferation and differentiation. Adv Immunol. 1992;52:125-262.

Bartholdy B, Matthias. Transcriptional controlo $f$ B cell development and function. Gene. 2004;327(1):1-23.

Bates CA, Ellison MC, Lynch DA, Cool CD, Brown KK, Routes JM. Granulomatouslymphocytic lung disease shortens survival in common variable immunodeficiency. $J$ Allergy Clin Immunol. 2004;114(2):415-21.

Bayry J, Hermine O, Webster DA, Levy Y, Kaveri SV. Common variable immunodeficiency: the immune system in chaos. Trends Mol Med. 2005;11(8): 3706.

Bayry J, Lacroix-Desmazes S, Kazatchkine MD, Galicier L, Lepelletier Y, Webster D, Levy Y, Eibl MM, Oksenhendler E, Hermine O, Kaveri SV. Common variable immunodeficiency is associated with defective functions of dendritic cells. Blood. 2004;104(8):2441-3.

"De acordo com:

International Commitee of Medical Journal Editors. Uniform requirements for manuscripts submitted to Biomedical Journal: sample references. Available from: http://www.icmje.org [2007 May 22]. 
Beard NA, Laver DR, Dulhunty AF. Calsequestrin and the calcium release channel of skeletal and cardiac muscle. Prog Biophys Mol Biol. 2004;85(1):33-69.

Berland $\mathrm{R}$, Wortis $\mathrm{HH}$. Origins and functions of $\mathrm{B} 1$ cells with rotes on the role of cd5. Annu Rev Immunol. 2002;20:253-300.

Boncristiano M, Majolini MB, D’Elios MM, Pacini S, Valensin S, Ulivieri C, Amedei A, Falini B, Del Prete G, Telford JL, Baldari CT. Defective recruitment and activation of ZAP-70 in common variable immunodeficiency patients with $\mathrm{T}$ cell defects. Eur $\mathrm{J}$ Immunol. 2000; 30(9): 2632-8.

Bordon A, Bosco N, Du Roure C, Bartholdy B, Kohler H, Matthias G, Rolink AG, Matthias $\mathrm{P}$. Enforced expression of the transcriptional co-activator OBF1 impairs B cell differentiation at the earliest stage of development. Plos One. 2008;3(12):e4007.

Bourke E, Bosisio D, Golay J, Polentarutti N, Mantovani A. The toll-like receptor repertoire of human $B$ lymphocytes: inducible and selective expression of TLR9 and TLR10 in normal and transformed cells. Blood. 2003;102:956-63.

Boyce M, Yuan J. Cellular response to endoplasmic reticulum stress: a matter of life or death. Cell Death Differ. 2006;13(3):363-73.

Brack C, Hirama M, Lenhard-Schuller R, Tonegawa S. A complete immunoglobulin gene is created by somatic recombination. Cell. 1978;15(1):1-14.

Brouet JC, Chedeville A, Fermand JP, Royer B. Study of the B cel memory compartment in common variable immunodeficiency. Eur $\mathrm{J}$ Immunol. 2000; 30(9):2516-20.

Busslinger M. Transcriptional control of early B cell development. Annu Rev Immunol. 2004;22:55-79.

Caldwell CW, Patterson WP. Relationship between CD45 antigen expression and putative stages of differentiation in B-cell malignancies. Am J Hematol. 1991;36:1115.

Calfon M, Zeng H, Urano F, Till JH, Hubbard SR, Harding HP, Clark SG, Ron D. IRE1 couples endoplasmic reticulum load to secretory capacity by processing the XBP-1 mRNA. Nature. 2002;415(6867):92-6.

Caraux A, Klein B, Paiva B, Bret C, Schmitz A, Fuhler GM, Bos NA, Johnsen HE, Órfão $A$, Perez-Andres $M$. Circulating human and plasma cells Age-associated changes in counts and detailed characterization of circulating normal CD138 and $\mathrm{CD} 138^{+}$plasma cells. Haematologica. 2010;95(6):1016-20. 
Carsetti R, Rosado M M, Wardmann H. Peripheral development of B cells in mouse and man. Immunol Rev. 2004;197:179-91.

Carulli G, Cannizzo E, Zucca A, Buda G, Orciuolo E, Marini A, Petrini M. CD45 expression in low-grade $B$ cell non-Hodgkin's lymphomas. Leuk. Res. 2008;32(2):263-7.

Castigli E, Wilson S.A, Garibyan L, Rachid R, Bonilla F, Schneider L, Geha R.S. $\mathrm{TACl}$ is mutant in common variable immunodeficiency and IgA deficiency. Nat Genet. 2005;37(8):829-34.

Claudio E, Brown K, Siebenlist U. NF-kappa B guides the survival and differentiation of developing lymphocytes. Cell Death Differ. 2006;13:697-701.

Clauss IM, Gravallese EM, Darling JM, Shapiro F, Glimcher MJ, Glimcher LH. In situ hybridization studies suggest a role for the basic region-leucine zipper protein hXBP1 in exocrine gland and skeletal development during mouse embryogenesis. Dev Dyn. 1993;197:146-56.

Chang TY, Chang CG, Ohgami N, Yamauchi Y. Cholesterol sensing, trafficking and esterification. Annu Rev Cell Dev Biol. 2006;22:129-57.

Conley ME, Notarangelo LD, Etzioni A. Diagnostic criteria for primary immunodeficiencies. Representing PAGID (Pan-American Group for Immunodeficiency) and ESID (European Society for Immunodeficiencies). Clin Immunol. 1999; 93(3):190-7.

Cox JS, Shamu CE and Walter P. Transcriptional induction of genes encoding endoplasmic reticulum resident proteins requires a transmembrane protein kinase. Cell. 1993; 73:1197-1206.

Credle JJ, Finer-Moore Papa FR, Stroud RM, Walter P. On the mechanism of sensing unfolded protein in the endoplasmic reticulum. Proc Natl Acad Sci USA. 2005;102(52):18773-84.

Csala M, Banhegyi G, Benedetti A. Endoplasmic reticulum: a metabolic compartment. FEBS Lett. 2006;580(9):2160-5.

Cunningham-Rundles, C. Clinical and immunologic analysis of 103 patients with common variable immunodeficiency. J Clin Immunol. 1989;9(1):22-33.

Cunningham-Rundles C. Common variable immunodeficiency: clinical and immunological features of 248 patients. Clin Immunol. 1999;93(3):190-7. 
Cunningham-Rundles $\mathrm{C}$. Hematologic complications of primary immune deficiencies. Blood Rev. 2002;16:61-4.

Cuss AK, Avery DT, Cannons JL, Yu LT, Nichols KE, Shaw PJ, Tangye SG. Expansion of functionally immature transitional B cell is associated with human immunodeficient states characterized by impaired humoral immunity. J Immunol. 2006;176(3):1506-16.

Daniels JA, Lederman HM, Maitra A, Montegomery EA. Gastrointestinal tract pathology in patients with common variable immunodeficiency (CVID):a clinicopathologic study and review. Am J Surg Pathol. 2007;31:1800-12.

Dasari P, Nicholson IC, Hodge G, Dandie WG, Zola H. Cell Immunology. 2005; 236:140-5.

Dawes R, Petrova S, Lui Z, Wraith D, Beverley PC, Tchillinan EZ. Combinations of CD45 isoforms are crucial for immune function and disease. $J$ Immunol. 2006;176(6):3417-25.

Deaglio S, Mehta K, Malavani F. Human CD38: a revolutionary story of enzymes and receptors. Leuk Res. 2001;25(1):1-12.

Delespesse G, Suter U, Mossalayi D, Bettler B, Sarfati M, Hofstetter H, Kilcher E, Debre $P$, Dalloul A. Expression, structure and function of CD23 antigen. Adv Immunol. 1991;49:149-91.

Dempsy PW, Allison ME, Akkaraju S, Goodnow CC, Fearon DT. Cd3 of complement as a molecular adjuvant: bridging innate and acquired immunity. Science. 1996; 271(5247):348-50.

Fagraeus $A$. The plasma cellular reaction and its relation to the formation of antibodies in vitro. J Immunol. 1948;58(1):1-13.

Farrington M, Grosmarie LS, Nonoyama S, Fischer SH, Hollenbaugh D, Ledbetter JA, Noelle RJ, Aruffo A, Ochs HD. CD40 ligand expression is defective in a subset of patients with common variable immunodeficiency. Proc Natl Acad USA. 1994; 91(3):1099-103.

Franzoso G, Carlson L, Xing L. Requirement for NF-kappaB in osteoclast and B-cell development. Genes Dev. 1997;11(24):3482-96.

Fitzsimmons D, Hodsdon W, Wheat W, Maira SM, Wasylyk B, Hagman J. Pax-5 (BSAP) recruits ETs proto-oncogene family proteins to form functional ternary complexes on a B-cell-specific promoter. Genes Dev. 1996;10(17): 2198-211.

Fujimoto M, Bradney AP, Poe JC, Steeber DA, Tedder TF. Modulation of B lymphocyte antigen receptor signal transduction by a CD19/CD22 regulatory loop. 
Immunity. 1999;11(2):191-200.

Gass JN, Gufford NM, Brewer JW. Activation of an unfolded protein response during differentiation of antibody-secreting B cells. J Biol Chem. 2002; 277:49047-54.

Gass JN, Gunn KE, Sriburi R, Brewer JW. Stressed-out B cells? Plasma-cell differentiation and the unfolded protein response. Trends Immunol. 2004;25(1):17-24.

Glembotski CC. The role the unfolded protein response in the heart. J Mol Cell C. 2008;44(3):453-9.

Grimbacher B, Hutloff A, Schlesier M, Glocker E, Warnatz K, Dräger R, Eibel H, Fischer B, Schäffer AA, Mages HW, Kroczek RA, Peter HH. Homozygous loss of ICOS is associated with adult-onset common variable immunodeficiency. Nat Immunol. 2003;4(3):261-8.

Grossmann M, O'Reilly LA, Gugasyan R, Strasser A, Adams JM, Gerondakis S. The anti-apoptotic activities of Rel and RelA required during B-cell maturation involve the regulation of Bcl-2 expression. EMBO J. 2000;19(23):6351-60.

Good RA, Zak SJ. Disturbances in gamma globulin synthesis as expriments of nature. Pediatrics. 1956;18(1):109-49.

Guazzi V, Aiuti F, Mezzaroma I, Mazzetta F, Andolfi G, Mortillaro A, Pierdominici M, Fantini R, Marziali M, Aiuti A. Assessment of thymic output in common variable immunodeficiency patients by evaluation of $\mathrm{T}$ cell receptor excision circles. Clin Exp Immunol. 2002; 129(2):348-53.

Guo BC, Saxon A. B cell lines from a subset of patients with common variable immunodeficiency undergo enhanced apoptosis associated with an incresead display of CD95 (Apo-1/fas), diminsihed CD38 expression, and decresead IgG and IgA production. Cell Immunol. 1995;166(1):83-92.

Harding HP, Zhang Y, Ron D. Protein translation and folding are coupled by an endoplasmic-reticulum-resident kinase. Nature. 1999;21(1):271-4.

Hardy RR, Hayakawa K. B cell development pathways. Annu Rev Immunol. 2001; 19:595-621.

Haze K, Yoshida H, Yanagi H, Yura T, Mori K. Mammalian transcription factor ATF6 is synthesized as a transmembrane protein and activated by proteolysis in response to endoplasmic reticulum stress. Mol Biol Cell. 1999;10(11): 3787-99.

Hermaszewski RA, Webster AD. Primary hipogammaglobulinaemia: a survey of 
clinical manifestations and complications. Q L Med. 1993;86:31-42.

Hendershot LM. The ER function BiP is a master regulator of ER function. Mt Sinai J Med. 2004;71(5):289-97.

Hendershot LM. Identity of the immunoglobulin heavy-chain binding protein with the 78,000 dalton glucose-regulated protein and the role of posttranslational modifications in its binding function. Mol Cell Biol. 1988;8(10):4250-6.

Hoffkes HH, Schmidtke G, Uppenkamp M, Schmucker U. Multiparametric Immunophenotyping of Bcells in peripheral blood of healthy adults by flow cytometry. Clin Diagn Lab Immunol. 1996;3(1):30-6.

Hornung V, Rothenfusser S, Britsch S, Krug A, Jahrsdofer B, Giese T, Endres S, Hartmann G. Quantitative expression of toll-like receptor 1-10mRNA in cellular subsets of human peripheral blood mononuclear cells and sensitivitiy to $\mathrm{CpG}$ oligodeoxynucleotides. J.Immunol. 2002; 168(9):4531-7.

Huh Y, Andreeff M. Flow Cytometry. Clinical and research applications in hematologic malignancies. Hematol Oncol Clin North Am. 1994;8(4):703-23.

Hutloff A, Dittrich AM, Beier KC, Eljaschewitsch B, Kraft R, Anagnostopoulos I, Krozek RA. ICOS is an inducible T-cell cos-estimulator structurally and functionally related CD28. Nature 21. 1999;397(6716):263-6.

Janeway C, Apt L, Gitlin D. Agammaglobulinemia Trans Assoc Am Physicians. 1953; 66:200-2.

Kikutani, H. Molecular structure of human lymphocyte receptor for immunoglobulin $\mathrm{E}$. Cell. 1986; 47(5):657-665.

Kim U, Qin XF, Gong S, Luo Y et al. The B-cell-specific transcription coativator OCA$\mathrm{B} / \mathrm{OBF}-1$, Bob-1 is essencial for normal production of immunoglobulin isotypes. Nature. 1996;383:542-7.

Kimata Y, Ishiwata-Kimata Y, Ito T, Hirata A, Suzuki T, Oikawa D, Takeuchi M, Kohno K. Two regulatory steps of ER-stress sensor Ire1 involving its cluster formation and interaction with unfolded protein. J Cell Biol. 2007;179(1):75-86.

Kokron CM, Errante PR, Barros MT, Baracho GV, Camargo MM, Kalil J, Rizzo LV. Clinical and laboratory aspects of common variable immunodeficiency. An Acad Brás Cienc. 2004;76(4):707-26.

Kondratenko I, Amlot PL, Webster AD et al. Lack of specific antibody response in commom variable immunodeficiency (CVID) associated with failure in production of antigen-secific memory T cells. Clin Exp Immunol. 1997; 108(1):9-13. 
Kopecky O, Lukesova S. Genetics defects in common variable immunodeficiency. Int J Immunogenet. 2007;34(4):225-9.

Kozmik Z, Wang S, Dorfler P, Adams B. Busslingir M. The promoter of the CD19 gene is a target for the B-cell-specific transcription factor BSAP. Mol Cell Biol. 1992; 12(6):2662-72.

Kozutsumi Y, Segal M, Normington K, Gething MJ and Sambrook J. The presence of malfolded proteins in the endoplasmic reticulum signals the induction of glucoseregulated proteins. Nature.1988; 332:462-4.

Kuribayashi JS, Bombardieri CR, Baracho GV, Aliberti J, Machado FS, Kalil J, Guilherme L, Kokron CM, Rizzo LV, Camargo MM. Slower rescue of ER homeostasis by the unfolded protein response pathway associated with common variable immunodeficiency. Mol Immunol. 2008;45:2990-7.

Lafrenz D, Koretz S, Stratte PT, Ward RB, Strober S. LPS-induced differentiation of a murine B cell leukemia (BCL1): changes in surface IgM. J Immunol. 1982; 129(3):1329-35.

Lee AS. The ER chaperone and signaling regulator GRP78/BiP as a monitor of endoplasmic reticulum stress. Methods. 2005;35(4):373-81.

LeBien TW. Fates of human B-cell precursors. Blood. 2000;96(1):9-23.

Lindholm D, Wootz H, Korhonen L. ER stress and neurodegenerative diseases. Cell Death and Differ. 2006;13:385-92.

Livak KJ, Schmittgen DT. Analysis of relative gene expression data using real-time quantitaitve PCR and the 2-ddct method. Methods. 2001; 25:402-8.

Loken MR, Shah VO, Dattilio KL, Civin Cl. Flow cytometric analysis of human boné marrow. II. Normal B-lymphocyte development. Blood. 1987; 70:1316-24.

Mackay F, Figgett WA, Saulep D, Lepage M, Hibbs ML. B-cell satge and contextdependent requirements for survival signals from BAFF and the B-cell receptor. Immunol Rev. 2010;237(1):205-25.

Malavani F, Deaglio S, Funaro A, Ferrero E, Horenstein, AL., Ortolan E, Vaisitti T, Aydin S. Evolution and function of the ADP ribosyl cyclase/CD38 gene family in physiology an pathology. Physiol Rev. 2008;88(3):841-6.

Malaspina A, Moir S, Ho J, Wang W, Howell ML, O'Shea MA, Rehm CA, Mican JM, Chum TW, Fauci AS. Appearance of immature/transitional B cells in HIV-infected individuals with advanced disease: correlation with increased IL-7. Proc Natl Acad Sci U S A. 2006;103(7):2262-7. 
Marie-Cardine A, Divay F, Dutot J, Green A, Perdrix A, Boyer O, Contentin N, Tilly, $H$, Tron $F$, Vannier JP, Jacqueout S. Transitional B cells in humans: characterization and insight from lymphocyte reconstitution after hematopoietic stem cell transplantation. Clin Immunol. 2008;127(1):14-25

Matthias P, Rolink GA. Transcriptional networks in developing and mature B cells. Nat Rev Immunol. 2005;5(6):497-508.

Maza MO, Crabb E, Mitsuyasu RT, Fahey JL, Giorgi JV. Infection with the human immunodeficiency vírus (HIV) is associated with an in vivo increase in B lymphocyte activation and immaturity. J Immunol. 1987;138(11):3720-4.

McCullough KD, Martindale JL, Klotz LO, Aw TY, Holbrook NJ. Gadd 153 sensitizes cells to endoplasmic reticulum stress down-regulating BCL2 and perturbing the cellular redox state. Mol Cell Biol. 2001;21:1249-59.

McKenna RW, Washington LT, Aquino DB, Picker L, Kroft SH. Immunophenotypic analysis of hematogones (B-lymphocyte precursors) in 662 consecutive boné marrow specimens by 4-color flow cytometry. Blood. 2001; 98(8):2498-507.

Mellemkjaer L, Hammarstrom L, Andersen V, Yuen J, Heilmann C, Barington T, Bjorkander J, Olsen JH. Câncer risk among patients with IgA deficiency or common variable immunodeficiency and their relatives: a combined Danish and Swedish study. Clin Exp Immunol. 2002; 130:495-500.

Meunier L, Usherwood YK, Chung KT, Hendershot LM. A subset of chaperones and folding enzymes form multiprotein complexes in endoplasmic reticulum to bind nascent proteins. Mol Biol Cell. 2002;13:4456-69.

Milne CD, Paige CJ. IL-7: a key regulator of B lymphopoiesis. Semin Immunol. 2006; 18(1):20-30.

Mori K, Kawahara T, Yoshida H, Yanazi H and Yura T. Signalling from endoplasmic reticulum to nucleus: transcription factor with a basic-leucine zipper motif is required for unfolded protein-response pathway. Genes Cells. 1996; 1:803-17.

Muzio M, Bosisio D, Polentarutti N, D'amico G, Stoppacciaro A, Mancineli R, Van't veer C, Penton-Rol G, Ruço LP, Allavena P, Mantovani A. Differential expression and regulation of toll-like receptors (TLR) in human leukocytes: selective expression of TLR3 in dendritic cells. J.Immunol. 2000; 164(1):5998-6004.

Nakagawa T, Zhu H, Morishima N, Li E, Xu J, Yankner BA, Yuan J. Caspase-12 mediates endoplasmic-reticulum-specific apoptosis and cytotoxicity by amyloid-beta. Nature. 2000;403(6765):98-103. 
Nielsen PJ, Georgiev O, Lorenz B, Schaffner W. (1996). B lymphocytes are impaired in mice lacking the transcriptional co-activation Bob1/OCA-B/OBF1. Eur J Immunol. 1996;26(12):3214-8.

Nourizadeh M, Aghamohammadi A, Moazzeni SM, Mahdavi M, Jalili A, Rezaei N, Hadjati J. Altered dentritic cell function in response to sera of common variable immunodeficiency patients. Inflamm Res. 2007;56(12):527-32.

Nutt SL, Urbanek P, Rolink A, Busslinger M. Essencial functions of Pax5 (BSAP) in pro-B cell development: difference between fetal and adult lymphopoiesis and reduced V-to-DJ recombination at the IgH lócus. Genes Dev. 1997;11(4):476-91.

Okabe T, Bauer SR, Kudo A. Pré-B lymphocyte-specific transcriptional controlo $f$ the mouse $\mathrm{V}$ pre B gene. Eur J Immunol. 1992;22(1):31-6.

O'Riordan M, Grosschedl R. Coordinate regulation of B cell differentiation by the transcription factors EBF and E2A. Immunity. 1999;11(1):21-31.

Oslowski CM, Urano F. A switch from life to death in endoplasmic reticulum stressed beta-cells." Diabetes Obes Metab. 2010;12(Supp 2):58-65.

Park MA, Hagan JB, Maddox DE, Abraham RS. Common Variable Immunodeficiency: a new look at an old disease. Lancet . 2008; 372(9637):489-502.

Patrick FK, Yong MRCP, Michael T, Ignatius C, Bodo G, Ronnie C. Common Variable Immunodeficiency: An Update on Etiology and Management. Immunol Allergy Clin N Am. 2008;28:367-86.

Piqueras B, Lavenu-Bombled C, Galicier L, Bergeron-van der Cruyssen F, Mouthon L, Chevret S, Debré P, Schmitt C, Oksenhendler E. Common variable immunodeficiency patient classification based on impaired B cell memory differentiation correlates with clinical aspects. J Clin Immunol. 2003;23(5):385-400

Ramon SS, Radigan L, Yu JE, Bard S, Cunningham-Rundles C. Memory B cells in common variable immunodeficiency: Clinical associations and sex differences. Clin Immunol. 2007;128(3):314-21.

Reimold AM, Etkin A. Clauss I, Perkins A, Friend DS, Zhang J, Horton HF, Scott A, Orkin SH, Byrne MC, Grusby MJ, Glimcher LH. An essencial role in liver development for transcription factor XBP-1. Genes Dev. 2000;14:152-7.

Reimold AM, Iwakoshi NN, Manis J, Vallabhajosyula P, Szomolanyi-Tsuda E, Gravallese EM, Friend D, Grusby MJ, Alt F, Glimcher LH. Plasma cell differentiation requires the transcription factor XBP-1. Nature. 2001;412(6844):300-7. 
Ritter C, Helenius A. Recognition of local glycoprotein misfolding by the ER folding sensor UDP-glucose:glycoprotein glucosyltransferase. Nat Struct Biol. 2000; 7(4):278-80.

Rolink A, Melchers F. B lymphopoiesis in the mouse. Adv Immunol. 1993;53:123-56

Rutkowski DT, Kaufman RJ. A trip to the ER: coping with stress. Trends Cell Biol. 2004;14(1):20-8.

Ryu EJ, Harding HP, Angelastro JM, Vitolo OV, Ron D, Greene LA. Endoplasmic reticulum stress and the unfolded protein response in cellular models of Parkinson's disease. J. Neurosci. 2002;22:10690-8.

Salzer U, Chapel HM, Webster AD, Pan-Hammarstrom Q, Schmitt-Graeff A, Schlesier M, Peter HH, Rockstroh JK, Schneider P, Schaffer AA, Hammarstrom L, Grimbacher B. Mutations in TNFRSF13B encoding TACl are associated with common variable immunodeficiency in humans. Nat Genet. 2005;37(8):820-8.

Samitas K, Lotvall J, Bossios A. B cells: From early development to regulating allergic diseases. Arch.Immunol Ther.Exp. 2010;58:209-15.

Saxon A, Sidell N, Zhang K. B cells from subjects with CVI can be driven to Ig production in response to CD40 stimulation. Cell Immunol. 1992;144(1):169-81.

Shaffer AL, Lin KI, Kuo TC, Yu X, Hurt EM, Rosenwald A, Giltnane JM, Yang L, Zhao $\mathrm{H}$, Calame K, Staudt LM. Blimp-1 orchestrates plasma cell differentiation by extinguishing the mature B cell gene expression program" Immunity. 2002;17:51-62.

Sheng Y, Hendershot L. Identification of ERdj3 and OBF-1/BOB-1/OCA-B as direct targets of XBP-1 during plasma cell diferentiation. J Immunol. 2007; 179: 2969-78.

Schesbesta M, Barry H, Meinrad B. Transcriptional control of B-cell development. Curr Opin Immunol. 2002;14(2):216-23.

Schliephake DE, Schimpl A. BLIMP-1 overcomes the block in IgM secretion in lipopolysaccharide/anti-mu $F\left(a b^{\prime}\right) 2$ co-stimulated B lymphocytes. Eur J Immunol. 1996; 26(1):268-71.

Schneider P. et.al. BAFF, a novel ligando of tumor necrosis factor (TNF) family, stimulates B-cell growth. J Exp Med. 1999;189(11):1747-56.

Schneider P. The role of APRIL and BAFF in lymphocyte activation. Curr Opin Immunol. 2005; 17(3):282-9.

Schroder M, Kaufman RJ. The mammalian unfolded protein response. Annu Rev Biochem. 2005;74:739-89.

Schroeder HWJr, Schroeder HW 3rd, Sheikh SM. The complex genetics of common 
variable immunodeficiency (CVID). J Investig Med. 2004;52(2):90-103.

Schubart DB, Rolink A, Kosco-Vilbois MH, Botteri F, Matthias P. B-cell specific coactivator OBF-1/OCA-B/Bob1 required for immune response and germinal centre formation. Nature. 1996;383(6600):538-42.

Schwartz R, Porat YB, Handzel Z, Sthoeger Z, Garty BZ, Confino-Cohen R, Levy J, Zan-Bar I. Identification of a subset of common variable immunodeficiency patients with impaired B-cell protein tyrosine phosphorylation. Clin Diagn Lab Immunol. 1999;6(6):856-60.

Scott-Taylor TH, Green MR, Raeiszadeh M, Workman S, Webster AD. Defective maturation of dendritic cells in common variable immunodeficiency. Clin Exp Immunol. 2006;145(3):420-7.

Serke S, Schwaner I, Yordanova M, Szczepek A, Huhn, D. Monoclonal antibody FMC7 detects a conformational epitope on the CD20 molecule: evidence from phenotyping after rituxan therapy and transfectant cell analysis. Cytometry. 2001; 46(2):98-104.

Sidrauski C, Walter $\mathrm{P}$. The transmembrane kinase Ire1p a site-specific endonuclease that initiates mRNA splicing in the unfolded protein response. Cell. 1997;19 90(6):1031-9.

Sigvardsson M, O'Riordan M, Grosschedl R. EBF and E47 collaborate to induce expression of the endogenous immunoglobulin surrogate light chain genes. Immunity. 1997;7(1):25-36.

Sims GP, Ettinge R, Shirota Y, Yarboro CH, Illei GG, Lipsky PE. Identification and characterization of circulating human transitional B cells. Blood. 2005;105:4390-8.

Singh $\mathrm{H}$, Medina $\mathrm{KL}$, Pongubala JM. Contingent gene regulatory networks and $\mathrm{B}$ cell fate specification. Proc Natl Acad Sci U S A. 2005;102(14):4949-53.

Suzuki CK, Bonifacino JS, Lin AY, Davis MM, Klausner RD. Regulating the retention of $\mathrm{T}$ cell receptor alpha chain variants within the endoplasmic reticulum: $\mathrm{Ca}(2+)-$ dependent association with BiP. J Cell Biol. 1991;114(7):189-205.

Tan Y, Dourdin N, Wu C, De Veyra T, Elce JS, Greer PA. Ubiquitous calpains promote caspase-12 and JNK activation during endoplasmic reticulum stressinduced apoptosis. J Biol Chem. 2006;281:16016-24.

Tardif KD, Mori K, Siddiqui A. Hepatitis C virus subgenomic replicons induce endoplasmic reticulum stress activating an intracellular signaling pathway. J Virol. 2002;76(8):7453-9. 
Taubenheim N, von Hornung M, Durandy A, Warnatz K, Corcoran L, Peter HH, Eibel $\mathrm{H}$. Defined blocks in terminal plasma cell differentiation of common variable immunodeficiency patients. J Immunol. 2005;175(8):5498-503

Tedder R, Clement LT, Cooper MD. Discontinuous expression of a membrane antigen (HB-7) during B lymphocyte differentiation. Tissue Antigens. 1994;24(3):1409.

Tedder TF, Crain MJ, Kubagawa H, Clement LT, Cooper MD. Evaluation of lymphocyte differentiation in primry and secundary immunodeficiency diseases. J Immunol. 1985;135(3):1786-91.

Tedder TF, Inaoki M, Sato S. The CD19-CD21 complex regulates signal transdution thresholds governing humoral immunity and autoimmunity" Immunity. 1997; 6(2):10718.

Travers KJ, Patil CK, Wodicka L, Lockhart DJ, Weissman JS, Walter P. Functional and genomic analyses reveal an essential coordination between the unfolded protein response and ER-associated degradation. Cell. 2000;101(3):249-58.

Tisilius A, Kabat EA. Electrophoresis of immune serum. Science. 1938;87(2262): 416-7.

van Anken E, Edwin PR, Claudia $M$ et al. Sequential waves of functionally related proteins are expressed when B cells prepare for antibody secretion. Immunity. 2003; 18:243-53.

Van Zelm MC, Reisli I, Van der Burg M, Castaño D, Van Noesel CJ, Van Tol MJ, Woellner C, Grimbacher B, Patiño PJ, Van Dongen JJ, Franco JL. An antibodydeficiency syndrome due to mutation in the CD19 gene. N Engl J Med. 2006;354 (18):1901-12.

Wang G, Yang ZQ, Zhang K. Endoplasmic reticulum stress response in cancer: molecular mechanism and therapeutic potencial. Am J Transl Res. 2010;2(1):65-74.

Warnatz K, Denz A, Drager R, Braun M, Groth C, Wolff-Vorbeck G, Eibel H, Schlesier M, Peter HH. Severe deficiency of switched memory B cells (CD27+lgMIgD-) in subgroups of patients with common variable immunodeficiency: a new approach to classify a heterogeneous disease. Blood. 2002;99:1544-51.

Wehr C, Kivioja T, Schmitt C, Ferry B, Witte T, Eren E, VIkova M, Hernandez M, Detkova D, Bos PR, Poerksen G, von Bernuth $H$, Baumann U, Goldacker S, Gutenberger S, Schlesier M, Bergeron-van der Cruyssen F, Le Garff M, Debré P, Jacobs R, Jones J, Bateman E, Litzman J, van Hagen PM, Plebani A, Schmidt RE, Thon V, Quinti I, Espanol T, Webster AD, Chapel H, Vihinen M, Oksenhendler E, Peter $\mathrm{HH}$, Warnatz K. The EUROclass trial:defining subgroups in common variable immunodeficiency. Blood. 2008;111(1):77-85. 
Werner ED, Brodsky JL, McCracken AA. Proteasome-dependent endoplasmic reticulum-associated protein degradation: an unconventional route to a familiar fate. Proc Natl Acad Sci U S A. 1996;93(11):13797-801.

Yoshida H, Matsui T, Yamamoto A, Okada T, Mori K. XBP1 mRNA is induced by ATF6 and spliced by IRE1 in response to ER stress to produce a highly active transcription factor. Cell. 2001;107:881-91.

Yoshida H, Matsui T, Hosokawa N, Kaufman RJ, Nagata K, Mori K. A timedependent phase shift in the mammalian unfolded protein response. Dev Cell. 2003; 4(2):265-71.

Yoshida H, Okada T, Haze K, Yanagi HT, Negishi M, Mori K. ATF6 activated by proteolysis binds in the presence of NF-Y (CBF) directly to the cis-acting element responsible for the mammalian unfolded protein response. Mol Cell Biol. 2000; 20(18):6755-67.

Zhang K, Shen X, Wu J. Endoplasmic reticulum stress activates cleavage of CREBH to induce a systemic inflammatory response. Cell. 2006;214:587-99.

Zinszner H, Kuroda M, Wang X, Batchvarova N, Lightfoot RT, Remotti H, Stevens J. L, Ron D. CHOP is impliated in programmed cell death in response to impaired function of the endoplasmic reticulum. Genes Dev. 1998;12(7):982-95.

Zola H, Neoh SH, Potter A, Melo JV, De Oliveira MS, Catovsky D. Markers of differentiated B cell leukaemia: CD22 antibodies and FMC7 react with different molecules. Dis Markers. 1987;5(4):227-35. 